\title{
برنامج قائم على التحليل الدلالي لتنمية مهارات الفهم القرائي للحديث النبوي الشريف لدى طالبات كلية الدراسات الإسلامية والعربية
}

هاني مملوله عبالنبي خضر

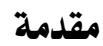

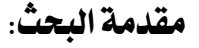

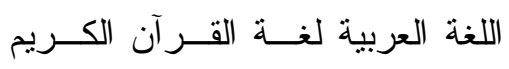

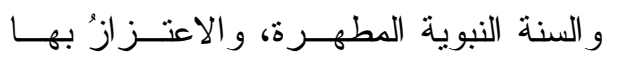

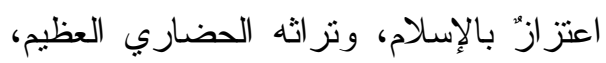

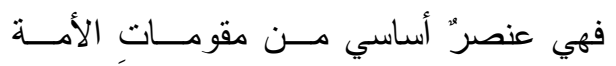

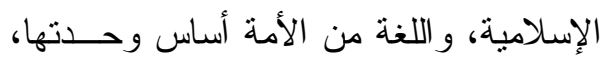

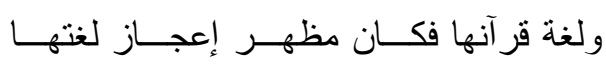
القومية.

ولهذا فاللغة العربية لها أهمية كبيــرة

في كونها لغة القرآن الكريم و السنة المطهرة،

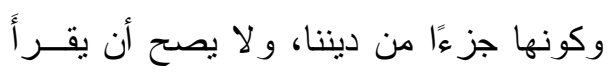

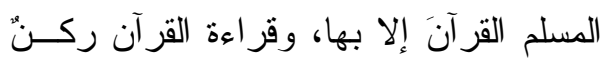
من أركان الصلاة، وتزداد أهميةُ تعلمِ اللغــــة العربية في كونها خيرَ معينٍ على فهم معاني القر آن الكريم و السنة المطهرة.

ولما كان القــر آن الكــريم محتويُّــا

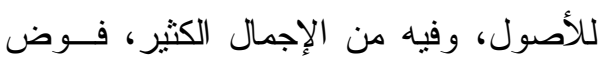

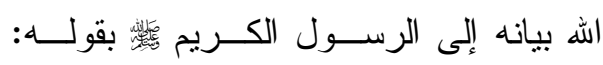

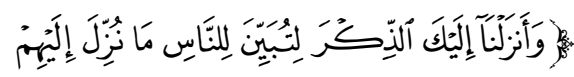

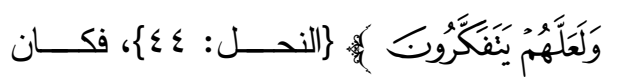

يهذف هذا البحث إلى تتمية مهــار ات

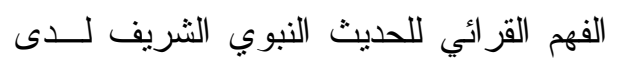

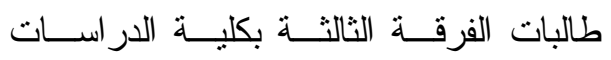

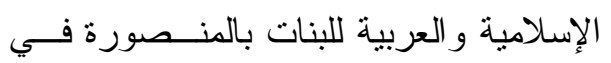

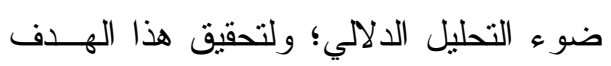
يعرض البحث خمـسة محسـاور كالتــالي،

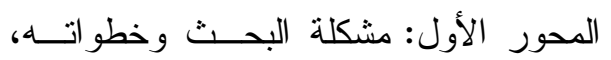

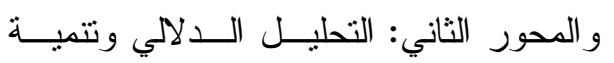

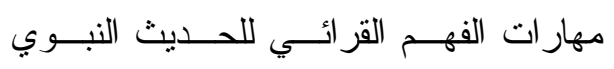

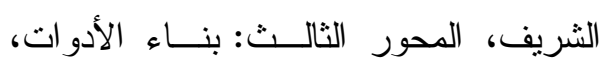

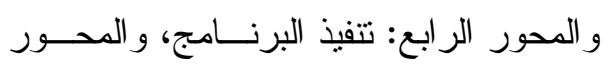

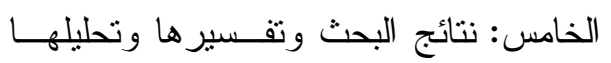

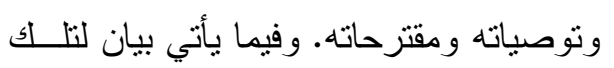
المحاور: المحور الأول: مشكلة البحث وخطواته: هدف هذا الفصل إلى تحديد مـشكلة

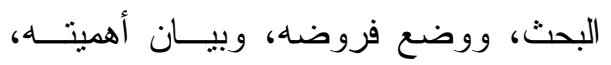

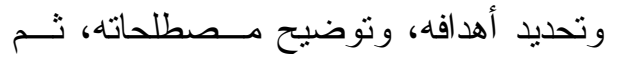
وصف الخطوات و الإجر اءات التي قام بهـــا

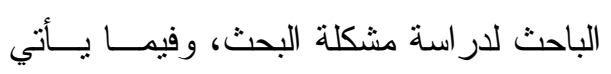

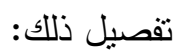


مهم، هو ما كلف الله به العباد مــن عقائـــ و عبادات ومعاملات و أخلاق و غير ذلك. ومن النماذج التي تدُلٌ على أنَّ السُّنة تُبيِّن ما أبهم في كتاب الله تعالى، قوله تعالى:

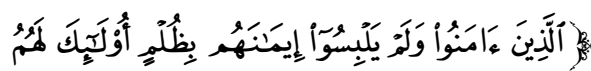

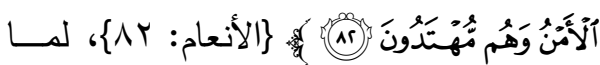

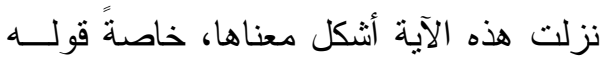

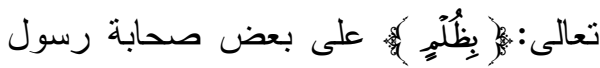
الله

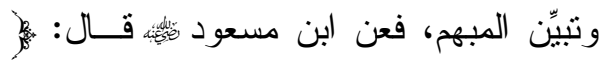

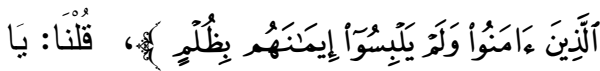

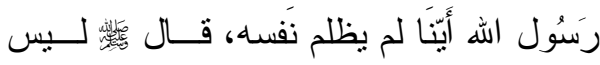

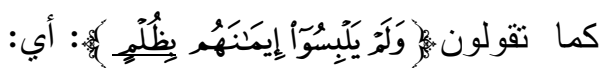

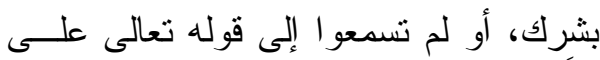
لسان ل لقمان

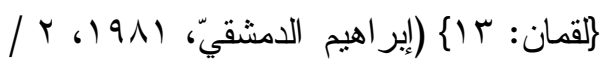
. ( ) VA

مما سبق يمكن القول إنَّــهُ لا يمكـنـ

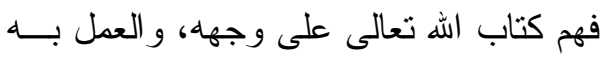

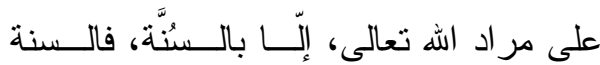
النبوية لها مكانة عظيمة في هذا الدين؛ لأنها المفسرة للقرآن الكريم، والمبينة له، ولمكانة السنة من الدين، ومنزلتها من القرآن الكــــيم عُنيَ الصحابة بالأحاديث النبوية عناية فائقة،

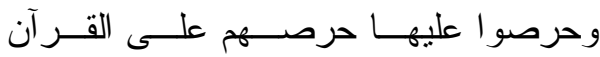

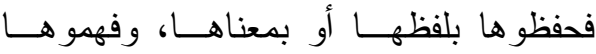

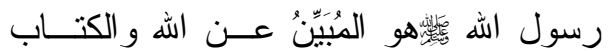
الناطق، و الرحمة المهداة.

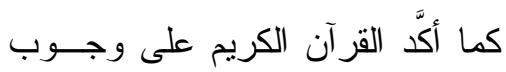

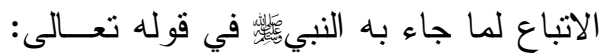

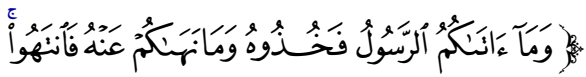

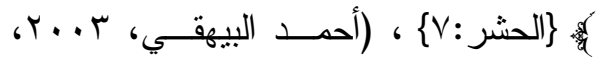

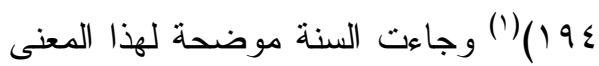

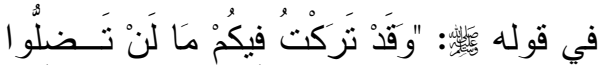

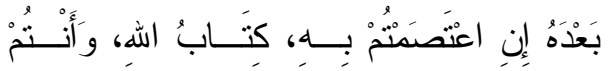

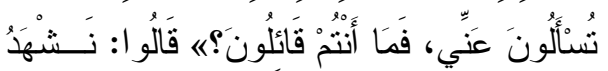

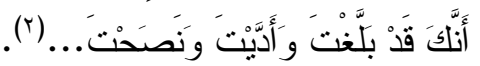
و السنة النبوية بعد الكتــاب العزيــز

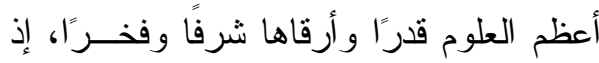
عليها بُنيَت قو اعد أحكام الشريعة الإسلامية، وبها تظهر تقاصيل مجملات الآيات القر آنية، وكيف لا ومصدر ها عمـن لا ينطــق عـن مهن

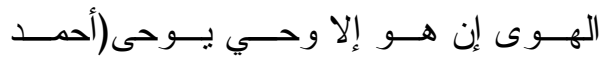

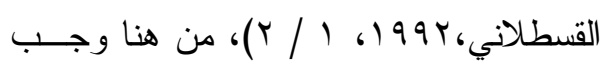

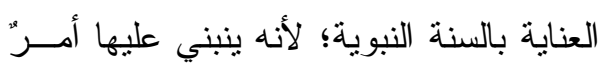
(1) يتبع الباحث نظام التوثيق الآتي: اسم الباحست أو

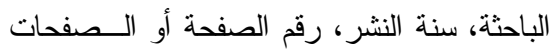

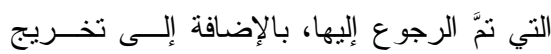
الأحاديث النبوية في هامش الصفحة. بالإنا

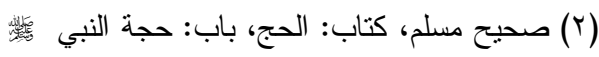

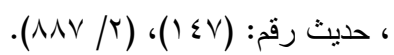


للحديث النبوي؛ لأنَّه يعتمد على تتمية القدرة

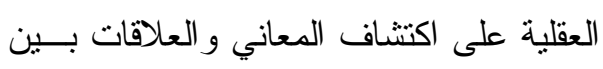
مكونات النص.

فبيان المعنى اللغوي لكلمة ما يتحقـق

بدر استها در اسة صوتية وصرفية ونحويــة

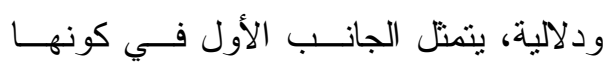

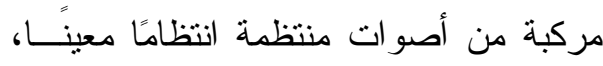
ويتمنل الجانب الثاني من معنى الكلمة فـي مئي

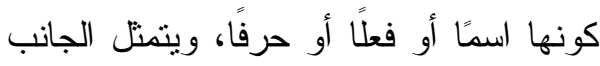
الثالث في بيان خصائصها النحوية من حيث

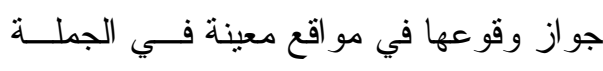
وارنباطها بغير ها من الكلمات التي تسبقها أو فو فئو

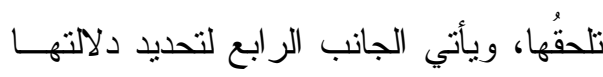
في سياقات متعددة تحديدًا دقيقًا. ودلالات الألفاظ تعد نقطـــة انطــاق

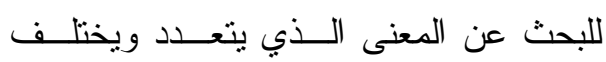
باختلاف السياق، و الدلالة هي المعنى، ودلالة أي لفظ هي ما ينصرف إليه هذا اللفظ فـي

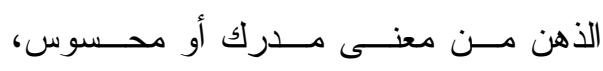

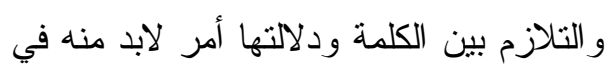

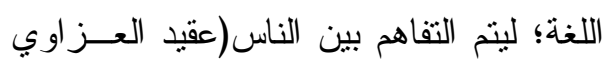

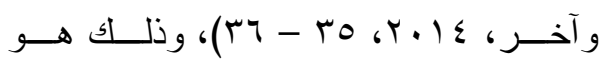
موضوع علم الدلالة.

فالبحث عن المعنى أساس كل نواصل

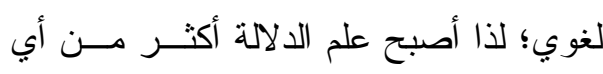

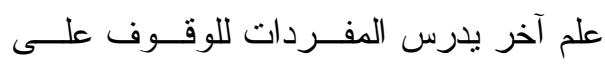
المعنى؛ لأنَّه هو القصد و النتيجة من إنتــاج
وعرفو ا مغازيها ومر اميها بسليقتهم وفطرتهم

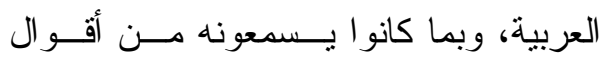

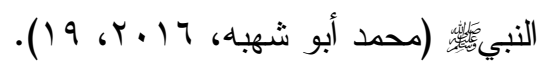
و الحــديث النبـــوي الــشريف منبـــع الفضائل، و أساس منظومة الأخــلاق و القــيم

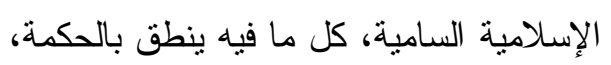

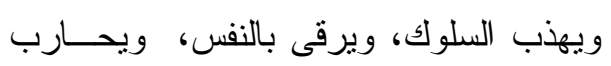

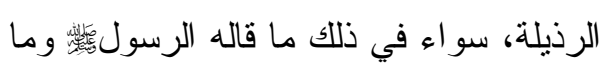

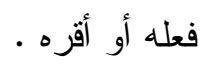

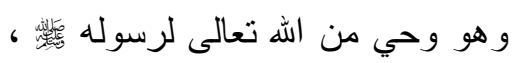

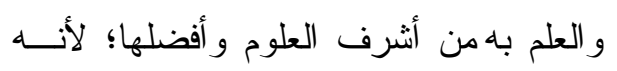

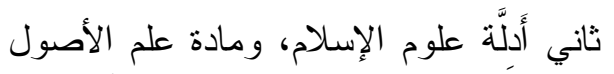

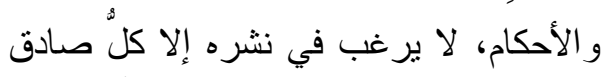

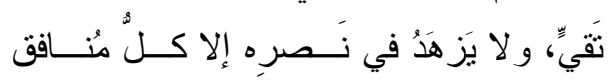

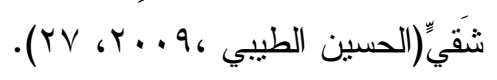
ونظرًا لمكانة الحديث و أهميته، فإنَّـهـ على كل مسلم عالم ومعلم و متعلم أن ينسلح بأدو ات دراسته، وتعلمه، وفهمه الذي يوصل

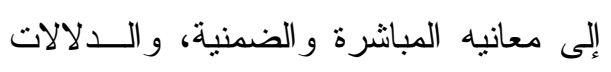

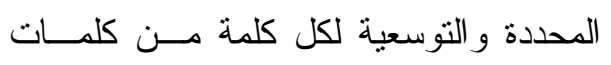
أحاديث رسول اله له

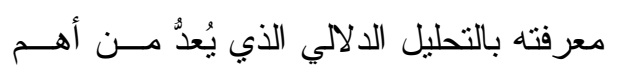

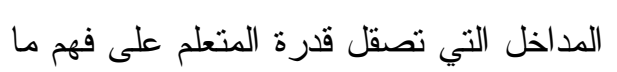
يقر أ من أحاديث النبي لئي

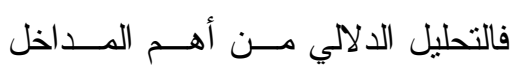

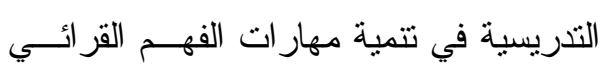


الحديث الثريف لاى طالبات الفرقـــة

السلسلة الكلامية، فعلم الدلالة هو علم دراسة الثالثة بكليــة الدراســـات الإســلامية

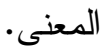

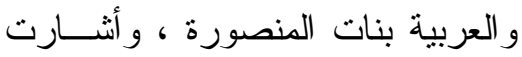

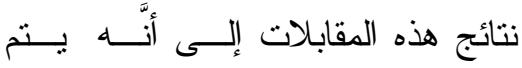

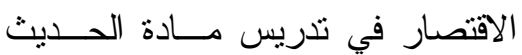

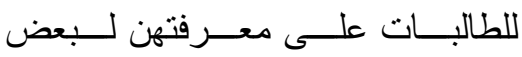
المعلومات عن الر اوي، ومعرفة معاني

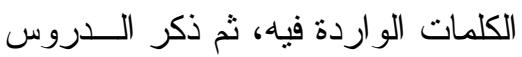
المستفادة منـــه، و واســتنباط الأحكــام الفقهية، و الوقوف على أوجه الإعراب، وتذوق الأسرار البلاغية، دون الاهتمام

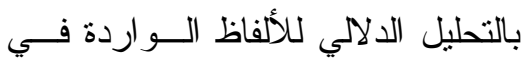

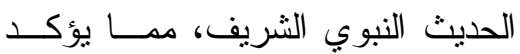

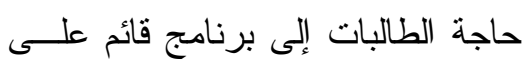

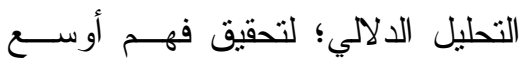
و أدق في تتمية مهار ات الفهم القرائسي للحديث النبوي.

\section{- تلوصـيات ونتـائج بعـض البحسوث والدراسـات}

1. في مجال الأحاديث النبوية:

- در اسة دالية حسين(ץ . . ץ): وكان مـن

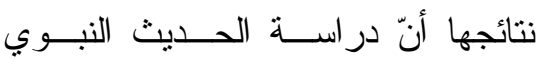

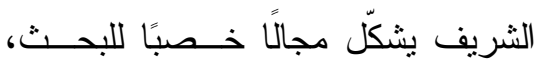
الذي ما زال بحاجة إلــى الكثيــر مــن لهن جهود الدارسين و الباحثين. - ودر اسة محمد إبر اهيم (0. . ب): الني

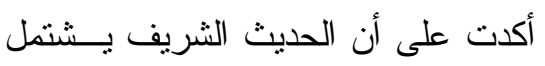

ولكون الحديث النبوي الثريف حقلــا

لغويا يحمل الكثير من الدلالات، ويحتاج كل

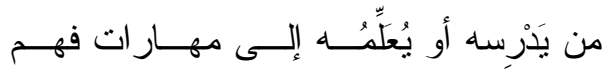

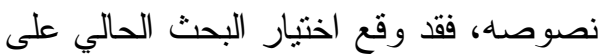
نصوص الحديث النبوي الــشريف؛ لنكـــون موضع النطبيق في برنامج مقترح قائم على

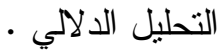

\section{الإحساس بالشكلة :}

استثعر الباحث هذه المشكلة من خلا:

- قيام الباحث بقر اءة وتحليل محتوى مادة الحديث للفرقة الثالثة بكلية الدراســات

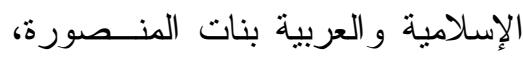

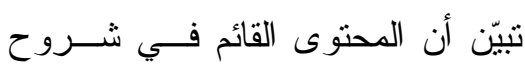

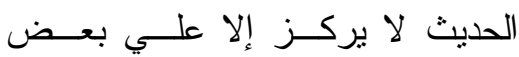

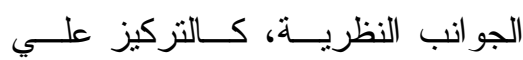

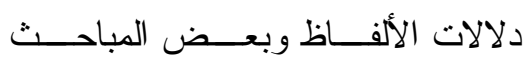

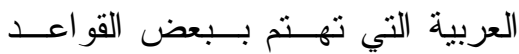

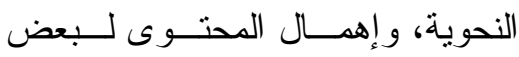
الجوانب الأخرى كدلالـــة الأســاليب،

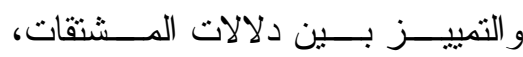
و التمييز بين الفروق اللغوية، وتَعـرَّت التطور الدلالي للألفاظ، وغير ها . - إجر اء الباحث لبعض اللقاءات مع بعض الأساتذة المتخصصين في تدريس مادة 


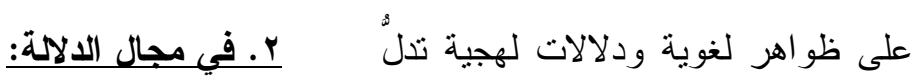

- دراسة صباح حلبـي (ب.... (ب): التـي

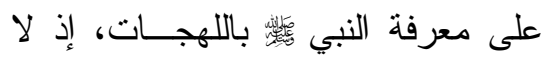
هدفت إلى در اسة الألفاظ الإسلامية فـي الهي يحيط باللغة إلا نبي. الأحاديث النبوية در اسة لغوية تهدف إلى الى الى الى

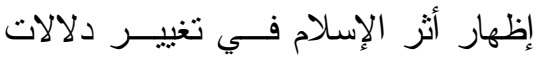

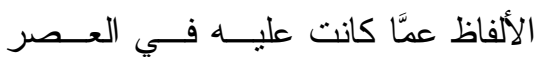

$$
\text { الجاهلي. }
$$

- ودر اسة محمد الدوري (0. . ب): التـي أكدت على ضــرورة معرفــة دلالات الألفاظ من خلال تفقدها في سياق الكلام

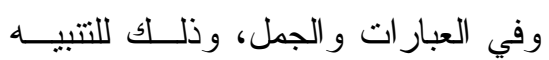

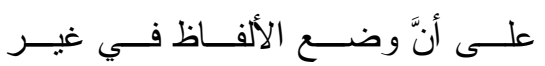

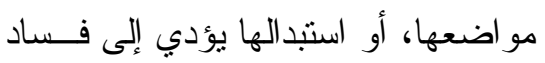

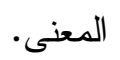

- ودراسة جنان الجبوري (0. • ب): التي

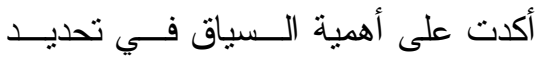
المعنى فلكل كلمة معنى، ولكل معنـى لهي وظيفة في النص الذي يؤلفه نظام خاص

$$
\text { من الكلمات. }
$$

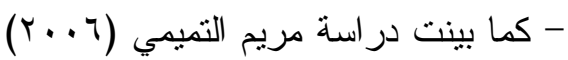

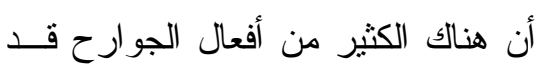
توسعت دلالتها ووصل قسم منها إلى حد التعبيم، حيث اختفى تدريجيًا اســتـعمالها اللغوي ليحل محله الاستعمال المجازي.

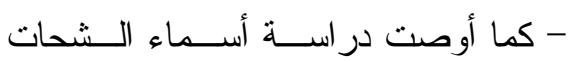

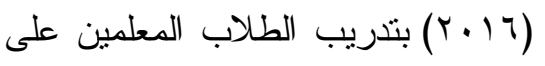
- ودر اسة عبد الرحمن منصور (9 . . ץ):

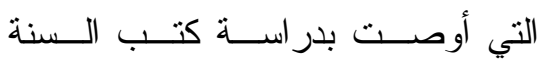

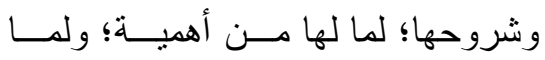
انشتملت عليه من الكثير مـن المباحــث لهن

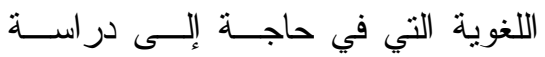
وتحليل.

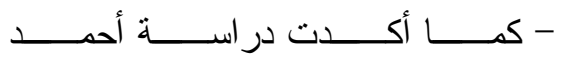

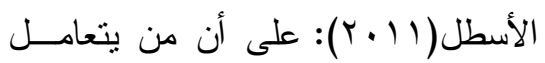

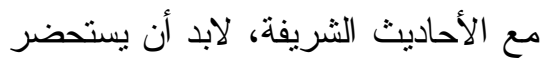

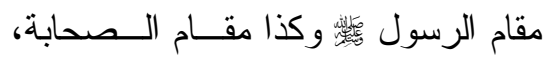

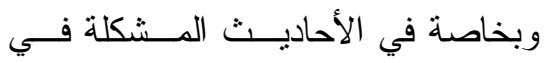
معناها، حتى يخرج بالدلالـــة المناسـبـة التي تر اعي المقام.

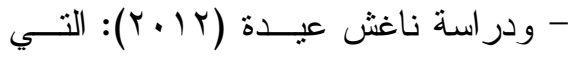
أوصت بإعطاء الحديث الشريف عنايـــة أكبر ومساحة أوسع في البحث و التحليل. - ودر اسة علي خلف الله (ع ( ب ب): التي

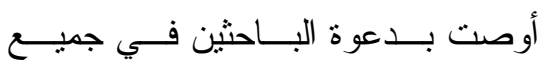
التخصـــصات إلــى در اســـة حــــيث

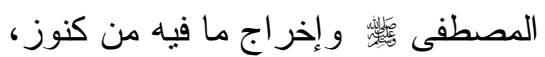

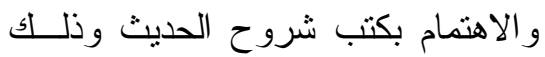
لاشتمالها على الكثير من القضايا اللغوية الجديرة بالدر اسة و التحليل . 


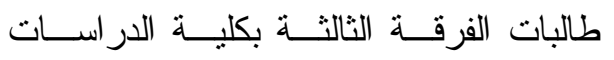

الإسلامية و العربية للبنات بالمنصورة؟

ويتفرع عن السؤال الرئيس الأسئلة الفرعية

التالية: ولزية

س ا: ما مهار ات الفهر القرائي للحــديث

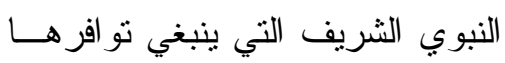

لاى طالبات الفرقـــة الثالثـــة بكليـــة

الدر اسات الإسلامية و العربية للبنــات

بالمنصورة:

سب: ما مدى تـــوافر مهـــار ات الفهــ

القرائي للحديث النبوي الثريف لدى

طالبات الفرقة الثالثة بكلية الدراسات

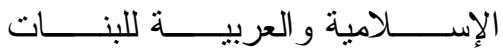

بالمنصورة

سَ: ما أسس البرنـــامج القــائم علــى

التحليل الدلالي لتتمية مهار ات الفهــ

القرائي للحديث النبوي الثريف لدى

طالبات الفرقة الثالثة بكلية الدراسات

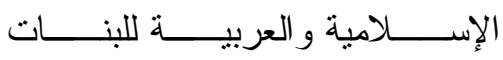

بالمنصور ة؛

سء : ما فاعلية البرنـــامج القــائم علــى

التحليل الدلالي لتتمية مهار ات الفهــ

القرائي للحديث النبوي الثريف لدى

طالبات الفرقة الثالثة بكلية الدراسات

الإسلامية للبنات بالمنصورة؟
استخدام الفروق الدلالية بــين الألفــاظ

القر آنية في أحاديثهم وكتاباتهم، وتضمين

بر امج إعداد وتــدريب معلمــي اللغـــة

العربية مقررًا عــن الفــروق الدلاليــة

ودر استه در اسة لغوية وتربوية.

لهذا يرى الباحث أهمية الدلالة فــي تحديـــ

المعنى المناسب للكلمات، وكذا أهميتها فـي

الأحاديث البوية الثريفة؛ للوقوف على تحديد

المعاني الدقيقة، ولتحقيق فهـــم أوســـع و أدق لأن

للحديث النبوي الثريف.

تحديل مشكلة البحث:

تحددت مشكلة البحث الحــالي فـي

ضعف مستوى طالبات الفرقة الثالثة - شعبة اللغة العربية- في كلية الدر اسات الإســلامية

و العربية بنات المنصورة في تتمية مهــار ات

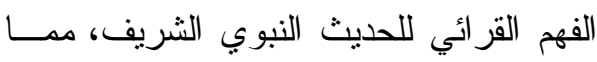
يستلزم البحث عن بر امج حديثة قائمة علــى التحليل الدلالي؛ لتمكن الطالبات مــن تتميــة مهار ات الفهــم القرائـي للحـــيث النبــــي الثريف.

وللتصدي لهذه المشكثة حاول البحث الإجابة

$$
\text { عن السؤال الرئيس التالي: }
$$

س: كيف يمكن بناء برنامج قائم على

التحليل الدلالي لتتمية مهار ات الفهم القرائـي

للحديث النبوي الثريف لــدى عينــة مــن 
لاى طالبــات الفرقــة الثالثــة بكليــة

الدر اسات الإســـلامية و العربيـــة بنـــات المنصورة.

- التحليل: كلمة تحليل تعني قدرة الفــرد على الفحص المدقق لمادة علميـــة مــــا،

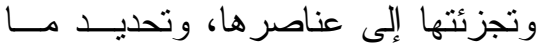
بينها من علاقات، وفهم البناء التتظيمي لها، فهو يختص بتحليل المعلومة إلـى أجز ائها مدا يساعد علــى فهــم و إدر الك

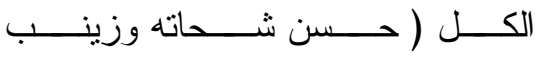

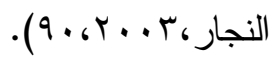
- والتحليل هو: عمليّة تقسيم الكـلـ إلــى أجزائه وردّ الثيّيء إلى عناصر ه، كمــــا

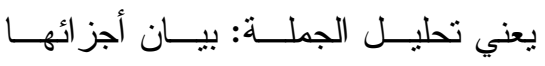

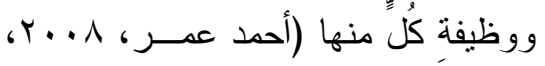
.00 . - الدلامة: الدلالة هي: العلـــم المخـــصّ

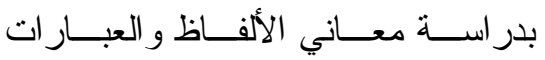
و التزّ اكيب اللُّغيَّة في سياقاتها المخنلفة. ويقصد بالتحليل الـــلالي إجرائيَّا: العملية التي يتم فيها تتاول ألفـــاظ الحــديث النبوي الثريف بالدر اسة و التحليل؛ لتعــرُّف دلالة أو معنى أي لفظ فيها، وما بين اللفظـــة ودلالتها من تلازم و علاقات بين الكلمــات، وذلك ببيان ما في نصوص الأحاديث النبوية من اشثتقاق، أو تز ادف، أو تضـاد، أو تعليـلـل
دار البحث الحالي في الحدود التالية:

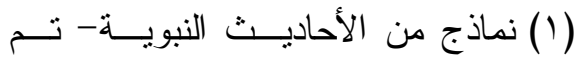

استخر اجها من صـــيحي البخــاري

ومسلم - لدى طالبات الفرقــة الثالثــة

شهبة اللغة العربية بكلية الدر اســات

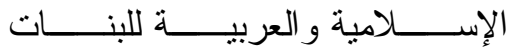

بالمنصورة، وفق أسس موضـــوعية

متعلقة بدر استهن، وتقابل اهتماماتهن.

(ץ) مهـــار ات الفهــــم القر ائـــي اللززمــــة

و المناسبة لطالبات الفرفة الثالثة بكلية الدراسات الإسلامية و العربية للبنــات

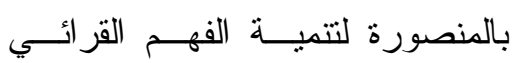
للحديث النبوي الثريف لايهن، و التي تمَّ تحديــدها عـن طريــق اســتبانة مضبوطة علميًا. (r) عينة من طالبات الفرقة الثالثة بكليــة الدر اسات الإسلامية و العربية للبنــات

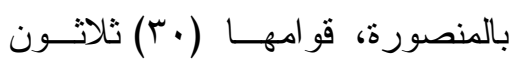
طالبة، نَّ اختيار ها عشو ائيًا. تحديل مصطلحات البحث:

- البرنامـج، يعرفه الباحث إجرائيًا بأنـــهـ: مجموعة الخبرات المتضمنة في دروس الحديث النبوي الثريف و القائمـــة فــي معالجتها على التحليل الدلالي للأحاديث، و الهادفة إلى تتمية مهار ات الفهم القرائي 
مجموعة من العمليات و المهـــار ات العقليـــة

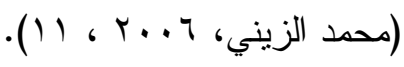

ويعرفه الباحث إجرائيًا بأنه: إعمــال

العقل في تحديد مدلو لات الألفاظ الواردة في

الأحاديث النبوية الثريفة وما بــين اللفظـــة ودلالتها من تلازم وعلاقات بين الكلمـات، وذللك ببيان ما في نصوص الأحاديث النبوية من اثتقاق، أو تز ادف، أو تضاد، أو تعليـلـل

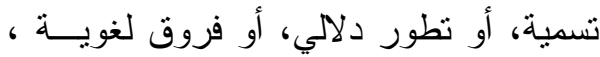

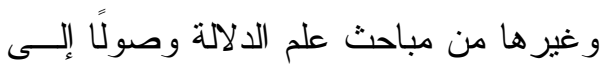
تحديد معانيها الدقيقة.

- الحديث النبوي الثريف: هو مَسـا

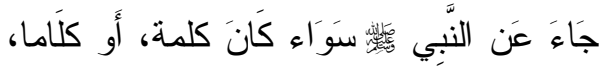

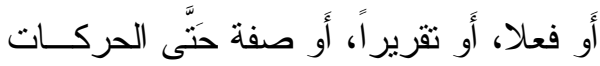
و السكنات، يقظة أَّو مناما.

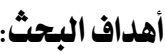

تمثَّتَت أهداف البحث الحــالي فــي تنميــة مهارات الفهم القرائـــي للحـــيث النبــوي الثريف من خلا الإجراءات التالية: (1) إعداد قائمة بمهار ات الفهـم القرائـي

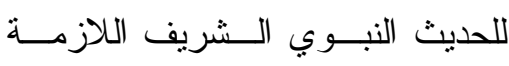
و المناسبة لطالبات الفرقة الثالثة بكلية الدر اسات الإسلامية و العربية للبنــات

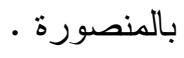

(Y) إعداد برنامج قائم على التحليل الدلالي لتتمية مهار ات الفهم القر ائي للحــديث
تسمية، أو تطور دلالي، أو فروق لغويــة ، و غير ها من مباحث علم الدلالة. التتمية، يعرفها الباحث إجرائًا بأنها:

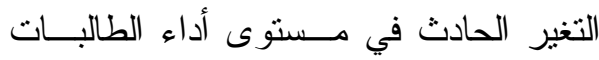
عينة البحث لمهارات الفهم القرائي للحــديث

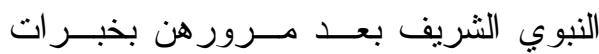

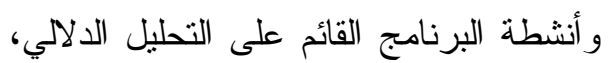

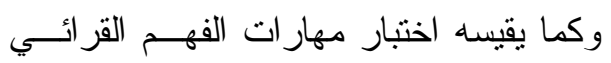
المعد لذلك. skill المهار ات: تعرف كلمة مهارة عند أهل التربية بأنها: أي شيء تعلمه الفرد

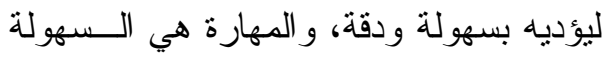

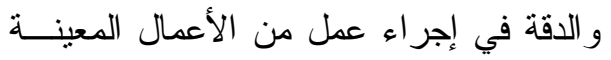

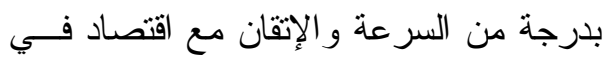

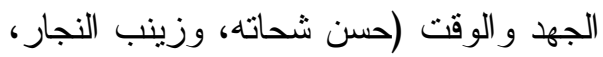
$\cdot r \cdot r \cdot r . . r$ وتعرف المهارات إجرائيًا بأنَّها: أداء الطالبات عينة البحث الــذي يتـسم بالدقـــة

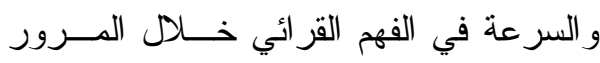
بخبرات و أنشطة البرنامج القائم على التحليل

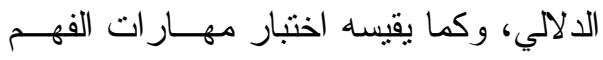
القر ائي المعد لذلك.

- الفهم القرائي: يعرف بأنه: ربــــ المعلومات المقروءة بالمخطط العقلي للقارئ ومخطط النص للتوصل إلى معنى من خلال بلى 
- اختبار مهار ات الفهم القرائــي للحــديث

النبوي الشريف لدى الطالبـات عينــة

$$
\text { البحث (إعداد الباحث). }
$$

- برنامج قائم على التحليل الدلالي لتنميـــة

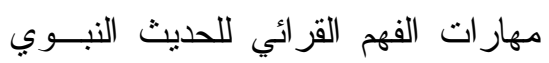

الثريف لدى الطالبــات عينـــة البحـــث

$$
\text { (إعداد الباحث). }
$$

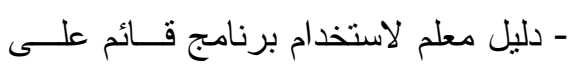

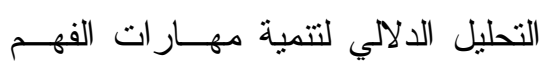

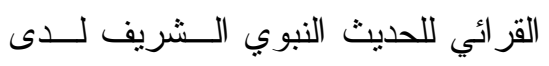

الطالبات عينة البحث (إعداد الباحث).

$$
\text { أهمية البحث: - (البح }
$$

نبعت أهمية البحث من أنَّه يمكـن أن

$$
\text { يفيد كنًا من: }
$$

- الطالبات: بتزويدهن بأحاديـــث نبويــــة

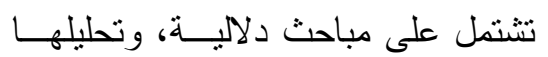

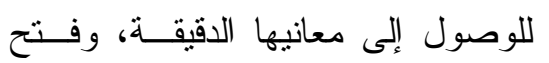

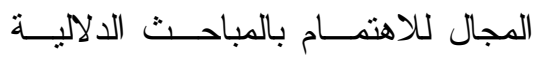

$$
\text { و التعرف عليها. }
$$

- المحاضرين : بتوجيه أنظار هم إلى أهمية

التحليل الدلالي في تتمية الفهم القرائسي لئي

للحديث النبوي الــشريف، نبـصيرهم

بمستويات الطالبات في مهار ات الفهـ

$$
\text { القر ائي للحديث النبوي الثريف. }
$$

- مخططي برنامج إعداد معلم اللغة العربية
النبوي الثريف لدى طالبات الفرقـــة

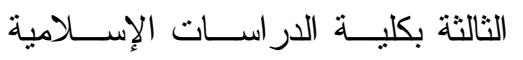
و العربية للبنات بالمنصورة.

(r) تحديد مدى فاعلية البرنامج القائم على

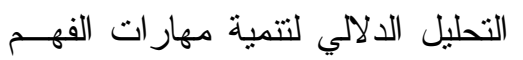
القرائي للحديث النبوي لاى طالبــات

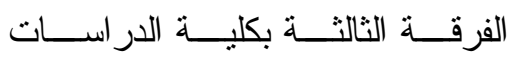

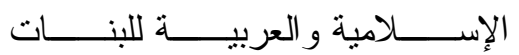

$$
\text { بالمنصورة. }
$$

\section{منهج البحث وتصميمه : - م}

أ - المنهج الوصفي التحليلي: وذلك فيما

يتعلق بدر اسة الأدبيــات و الدر اســات

السابقة ذات الصلة بموضوع لبعر البحث،

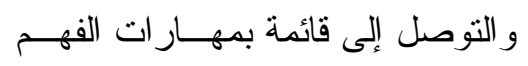

$$
\text { القر ائي للحديث النبوي الثريف. }
$$

ب - المنهج التجريبي: في الكثف عـن

فاعلية استخدام البرنامج القائم علـى فئى

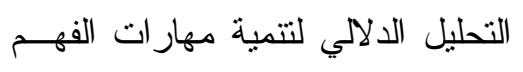

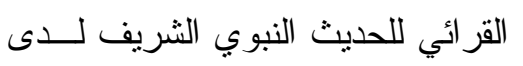

الطالبات عينة البحث.

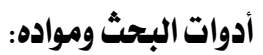

- استبانة لتحديد مهار ات الفهــم القرائـي

للحديث النبوي الثريف اللازمة لطالبات الفرقة الثالثة بكلية الدر اسات الإســـامية

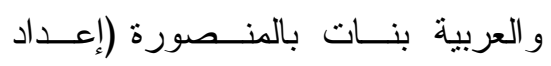
الباحث) 
كلإجابة عـن السؤال الأول الأي ينص على: س ا : ما مهارات الفهم القرائسـي للحـــيث

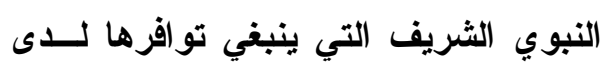
طالبات الفرقة الثالثة شعبة اللغة العربيـــة بكلية الدراسات الإسلامية و العربية للبنـات بالمنصورة؛ بليه قام الباحث بالإجر اءات الآتية: 1- إعداد قائمة مبدئية بالمهار ات المناسبة و اللازمة لطالبات الفرقة الثالثة بكليــة

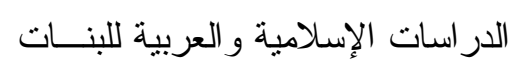
بالمنصورة في الفهم القرائي للحـديث

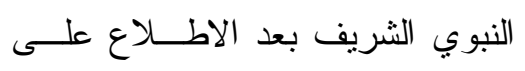
نتائج البحـــوث و الدر اســات الــــابقة

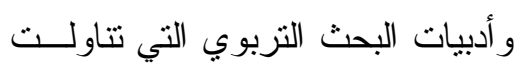

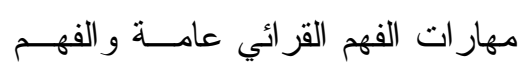
القر ائي للحــديث النبــوي الــشريف خاصة. ץ- عرض القائمة في صورة استبانة على مجموعة من المحكمين المتخصصين في اللغة العربية وطر ائسـق تدريسـسها

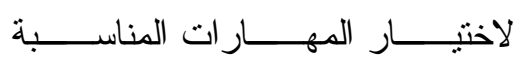
و اللازمة لطالبات الفرقة الثالثة بكليــة

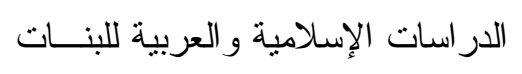

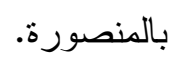

- فتح المجال للاهنمام بتتمية مهار ات الفهم

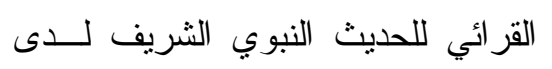

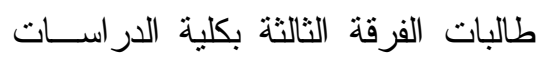
الإسلامية و العربية للبنات بالمنصورة. - إمدادهم بقائمة بمهار ات الفهـــم القرائسي

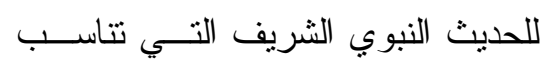

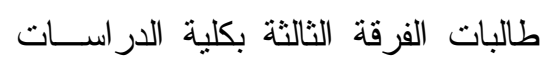
الإسلامية و العربية للبنات بالمنصورة. - إلقاء الضوء على التحليل الدلالي و الذي يُساعد على تتمية مهار ات الفهم القرائي

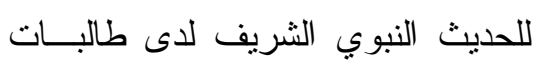

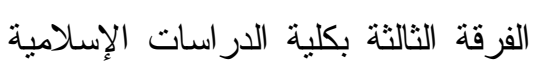
و العربية للبنات بالمنصورة.

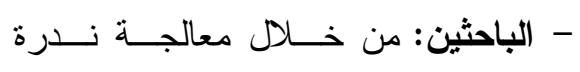

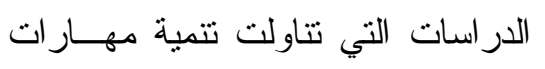

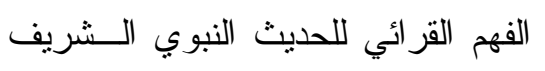
باستخدام البرنامج القائم على التحليـلـل لــل

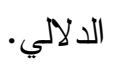
- فتح المجال أمام الباحثين لموضـــوعات

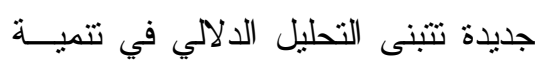
مهار ات ونصوص أدبية نسهم في إثراء البحث العلمي. خطوات البحث: للإجابة عن أســئلة البحــث الحـالي،

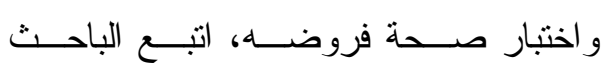


اللغة العربية بكلية الدراســات الإســلامية

$$
\text { و العربية للبنات بالمنصورة؟ لكه لئه }
$$$$
\text { قام الباحث بالإجر اءات الآتية: }
$$

* تصميم برنامج بهدف تتمية مهار ات الفهم

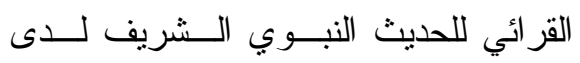

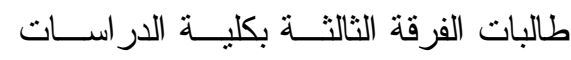

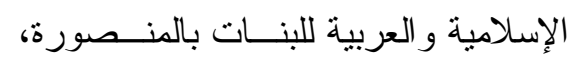

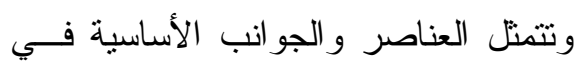
الإطار العام للبرنامج فيما يأتي:

1. الفلسفة التي يؤسس عليها البرنامج. r ـ تحديد أسس بناء البرنامج. r. مكونات البرنامج، وهي: • الأهداف التعليمية العامة و الخاصة. • المحتوي الدراسي المناسب لتحقبــق الأهداف المحددة، و العرض المفصل له، وخطته الدر اسية. • طر ائق تدريس البرنامج. • الوسائل و الأنشطة التعليمية، والتـي تساعد في تحقيق الأهداف المحددة.

$$
\text { • • - أساليب التقويم المتبعة. }
$$

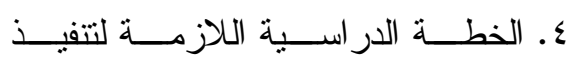
البرنامج، وتتمثل فيما يأتي:

$$
\text { • • • • الجدة التدريس. }
$$

r- تعـديل القائدـــة فــي ضـــو ء آراء

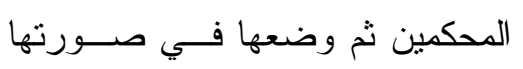
النهائية. للإجابة عن السؤال الثاني الأي ينص على: ما مدى توافر مهارات الفهم القرائي للحديث النبوي الثريف لاى طالبات الفرقة الثالثــة

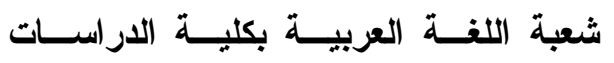
الإسلامية و العربية للبنات بالمنصورة؛ بله قام الباحث بالإجر اءات الآتية:

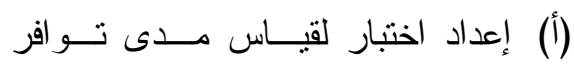
مهار ات الفهم القرائي للحديث النبوي الثريف لدى طالبات الفرقـــة الثالثـــة بكلية الدر اسات الإسلامية و العربيـــة للبنات بالمنصورة، وضبطه علميًا. (ب) تطبيق اختبار مهار ات الفهم القرائسي للحديث النبوي الثريف علــى عينــة عثوائية من طالبات الفرقــة الثالثــة بكلية الدر اسات الإسلامية و العربيــة للبنات بالمنصورة قبليًا. (ج) معالجة النتائج إحصائيًا. (د) التوصل للنتائج لمعرفة مدى تــو افر هذه المهار ات لاى الطالبات. للإجابة عن السؤال الثالث الأي ينص على:

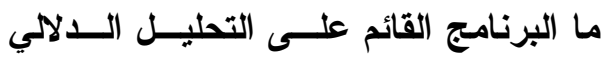
لتتمية مهارات الفهم القرائي للحديث النبوي الثريف لاى طالبات الفرقة الثالثة شــبة لتهبة 


$$
\text { * نقائج الدر اسة. التوصيات و المقترحات بناءً علـى }
$$

المحور الثـاني: التحليـل الـدلالي ودوره في تنميـة مهارات الفهم القرائي للحديث النبوي الشريف.

هدف هذا المحور إلى عـرض مـــا

يتصل بمتغيرات البحث من معطيات نظرية

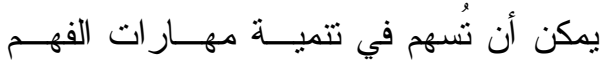
القرائي للحديث النبــوي الــشريف، وبنـــاء البرنامج القائم على التحليل الدلالي؛ ولتحقيق هذا الهدف يعرض هذا المحور ثلاثة عناصر رئيسة:

$$
\begin{aligned}
& \text { أولاًَ- الفهم القر ائي. } \\
& \text { ثانيًا- الحديث النبوي الثريف. }
\end{aligned}
$$

ثالثًا- التحليل الدلالمي ودوره في تتميــة

$$
\text { الفهم القرائي للحديث النبوي الثريف. }
$$

وفيما يلي عرض مفصل لهذه العناصر التي

$$
\text { تضمنهما هذا المحور: }
$$

$$
\text { أونًا- الفهم القرائي: }
$$

تتاول هذا العنــصر (مفهـوم الفهـح

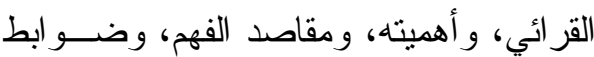

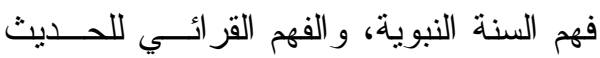

$$
\text { النبوي الثريف). }
$$

$$
1 \text { - مفهوم الفهم القرائي: }
$$

عرفه عبــدالمنعم رزق (1) • Y، (0)

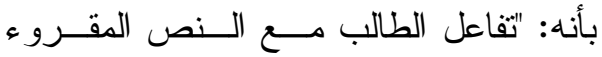
مستخدمًا خبر اته السابقة، وملامـــح الــنص
0. عرض البرنامج في صورته الأوليــة

على مجمو عة من الخبر اء و المحكمين

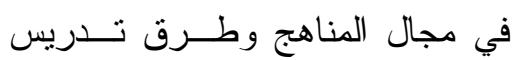

اللغة العربية؛ لتحديد مدى صــلاحية

$$
\text { البرنامج. }
$$

7. تعديل البرنامج في ضوء آراء الخبر اء

و المحكمين ووضــعه فــي صــورته

$$
\text { النهائية. }
$$

للإجابة عن السؤال الر ابع الذي ينص على: ما فاعلية البرنامـج القــائم علـــى التحليـلـل الدلالي لتنمية مهارات الفهم القرائي للحديث النبوي الثريف لاى طالبات الفرقة الثالثــة

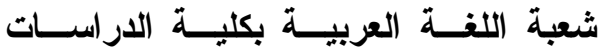

الإسلامية و العربية للبنات بالمنصورة؟

$$
\text { قام الباحث بالإجر اءات الآتية: }
$$

* إعداد دليل المعلم لتدريس البرنامج القائم

$$
\text { على التحليل الدلالي }
$$

* تدريس البرنامج المقترح لعينة البحث .

* تطبيق اختبار مهارات الفهــم القرائسي

للحديث النبوي الشريف بعديًا على عينة

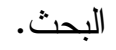

* جمع البيانات وتحليلها إحصائيًا.

* استخلاص نتائج الدراســة وتفـسير ها

$$
\text { و التعليق عليها. }
$$


قيادة للحياة بكل تفصيلاتها التي لم يتعـرض

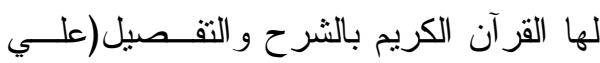

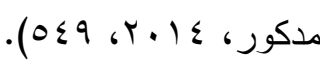

كما أنَّه يسهم في توسيع آفاق الطالبات

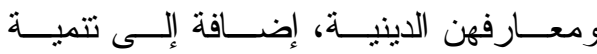
عو اطفهن الإسلامية

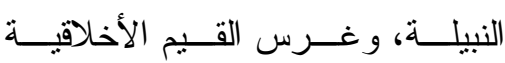
السامية، وتأكيد الثقة في نفوسهن بــصلاحية

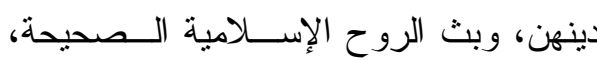
وتحقيق الانتماء الحي إلى أمة الإسلام. r- مقاصد الفهز:

المقاصد هي المعاني الملحوظة فــي

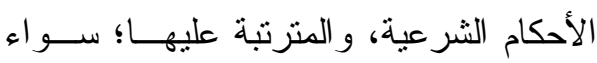
أكانت تلك المعاني حكما جزئية أم مــصالح كلية، وهي تتجمع ضمن هدف واحــد، هـــ تقرير عبودية الله ومـــلحة الإنـسـان فــي الدارين(نور الدين الخادمي، ( ... Y، V V). وصحة الفهم ركيزة رئيسـة لـصحة التلقي، و لا يستطيع المرءء أن يعرف مر اد الله عز وجل، ومر اد رسوله لهئ山 إلا حينما يستقيم فهمه لدلائل الكتاب و السنة، وكثير من البدع

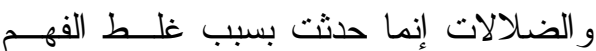
(خالد المطلق، 10 • ب، 10). ؛ - ضو ابط فهم السنة النبوية: الحديث الثريف له قو اعده وضــــو ابطه الخاصة، التي تعين على تسديد الفهم، وعدم
المقروء للوصول إلى المعاني المتضمنة في

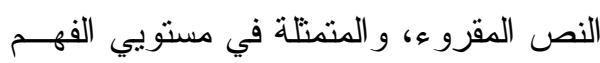
التذوقي و الإبداعي اللذين يقاسا بالدرجة الني

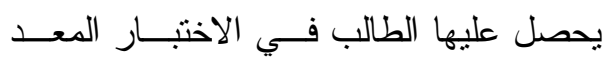
لذلك. ويمكن تعريف الفهم القرائسـي فــي البحث الحالي إجرائيًا بأنه: العمليات العقلية الثي تقوم بها طالبة الفرقـــة الثالثـــة بكليـــة

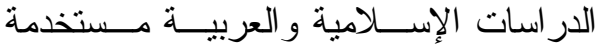
خبر اتها السابقة، للوصـــول إلــى المعــاني

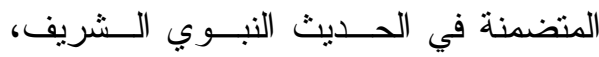
و المتمثلة في مسـستويات الفهــ (المباثــر ، و التذوقي، و الاستتناجي) و التي نقاس بالدرجة التي تحصل عليها الطالبة في الاختبار المعد لذلك.

r- أهمية الفهم القرائي للحديث النبوي: إنَّ مجرد التعـرف عافـى الكلمــات الموجودة في النص النبوي الثريف لا تصنع

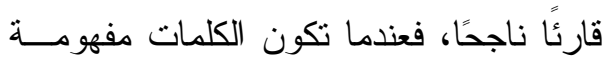

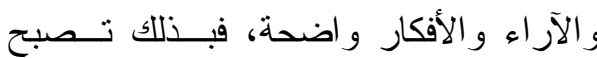
عملية القر اءة عملية صحيحة. و الحديث النبوي الثريف يعدُّ بمثابــة

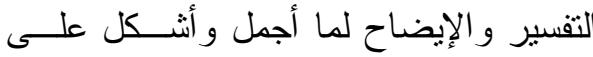

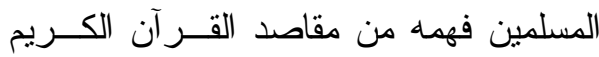

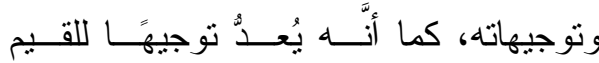

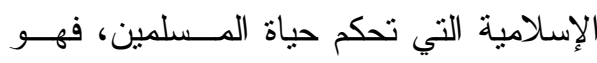


و هنالك أربع عشرة قاعدة ينبغي علـى

المشتغل بعلم الحديث الـشريف مر اعاتهــا، وهي:

1. التعرف على درجة الحديث من حيــث

$$
\text { القوة و الضعف. }
$$

r شرح الحديث حسـب قو اعــــ اللغـــة

العربية وأساليب العرب في البيان.

r. البعد عن التكلف في شرح الحديث.

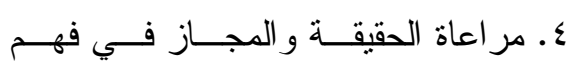

$$
\text { الحديث. }
$$

○. الفصل بين عالم الغيب و عالم الثهادة. آ. الوحي الــصحيح لا يعـارض العقـل الصريح.

V. فهم الحديث من خلال طرقه الأخرى.

1. فهم الحديث في ضو ء سبب وروده.

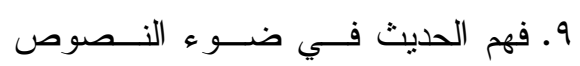

الثرعية الأخرى في الموضوع نفسه.

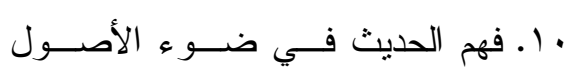

$$
\text { و القو اعد الشرعية. }
$$

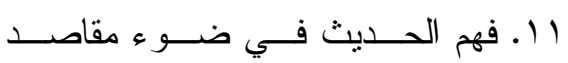

$$
\text { الثريعة. }
$$

rا ـ مر اعاة البعد الزماني و المكاني لألفاظ

$$
\text { الحديث. }
$$

با ـ مر اعاة المكتشفات العلمية الحديثة في

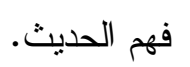

جنوحه عن الصواب، ومن الضوابط المهمة

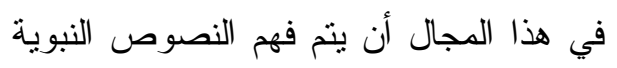

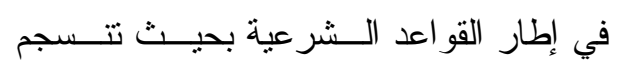
معها، و لا تتعارض مع مقتضاها. ولقد راعى شُراح الحديث الـشريف

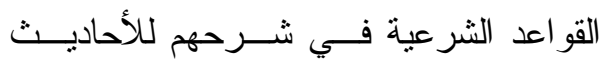

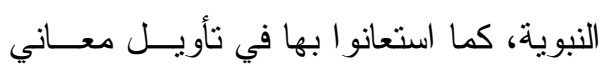

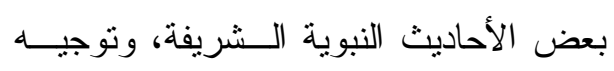

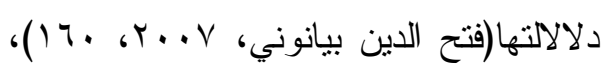

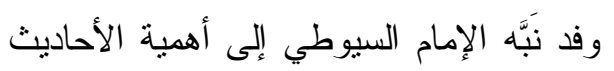

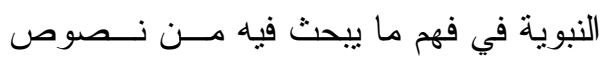

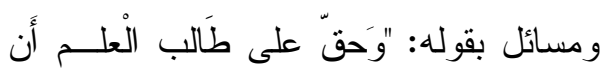

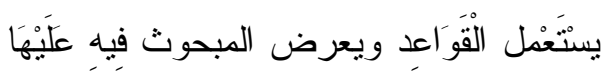

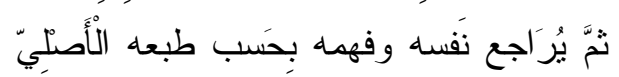

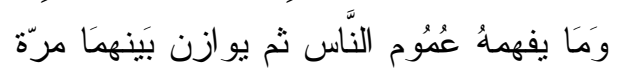

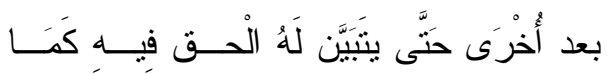

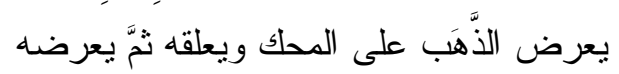

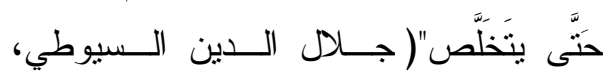
. (rTr 6) 979 هـ الفهم القرائي للحديث النبوي الثريف: الحديث النبوي الثريف هو: المصدر

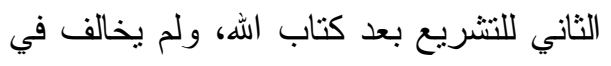

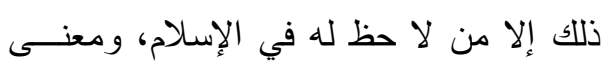

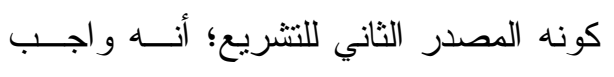
الإتباع و التتفيذ. 


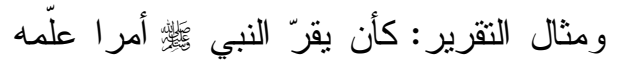
عن أحد من الصحابة من قول أو فعل. سواء

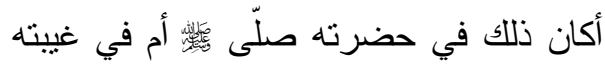

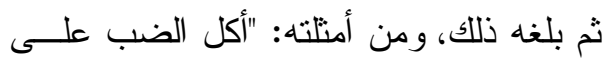

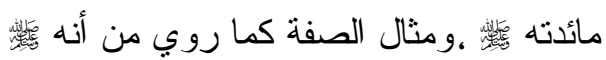

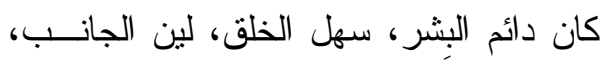

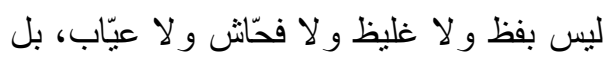

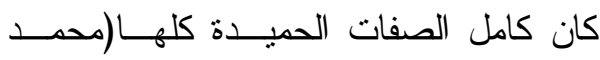

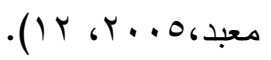
r- أهمية الحديث النبوي الثريف: تزجع أهمية الحديث في أنَّهَ المــصدر النتشريعي الثاني بعد القرآن الكريم الذي هـئه أصل الدين، ومنبع الطريق المستقيم .

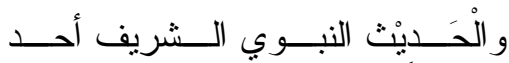

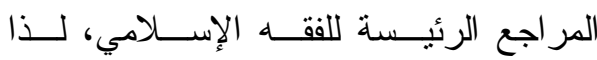

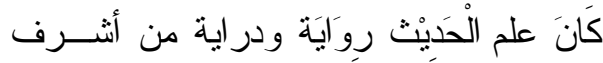

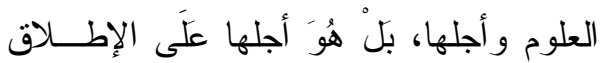

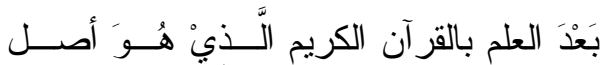

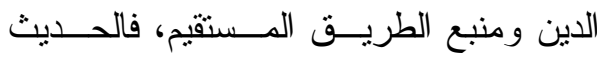

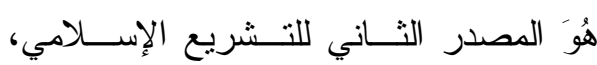

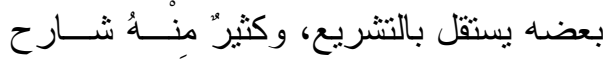

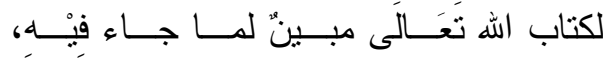

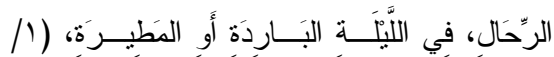
1 (1)، حديث رقم: (اיז)).
؟ ا. مر اعاة الاختلاف في فهم نــصوص

الحديث ات الدلالة الظنية(فتح الــدين بيانوني، V. . Y. . 10 - 101). وفهم الحديث النبوي الثريف لا يكفي له فهم المعنى اللغوي الوضعي، و إنما هـــ محتاج إلى إدراك العرف اللغوي و العــرف

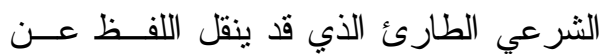
معناه إلى معنى آخر . ثانيًا - الحديث النبوي الشريف: تتاول هذا العنصر (مفهوم الحـديث، و أهميته، و أنواع السنة النبوية، ومنزلة السنة في الدين). 1 - مفهوم الحديث النبوي الثريف: الحديث النبوي هو : ما أضـــف إلــى النبي

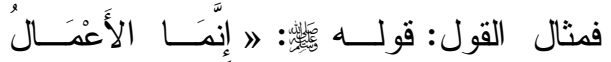

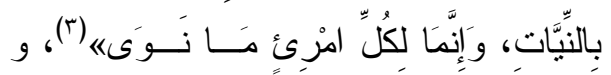

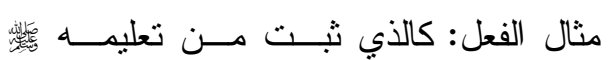

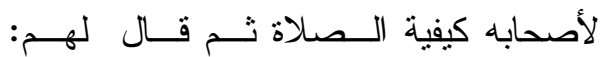

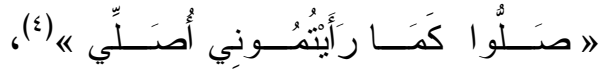
(1) أخرجه أبو داود في سننه، كتاب: الطلاق، باب:

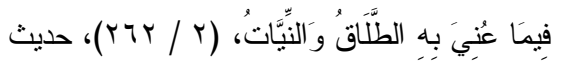

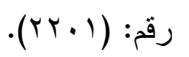

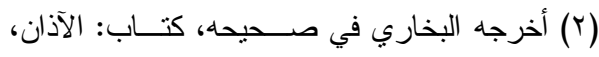

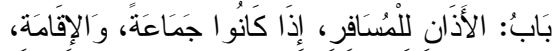

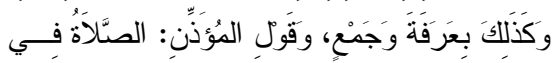




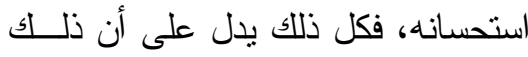

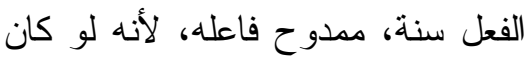

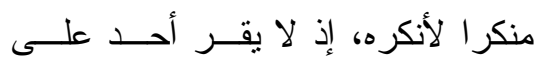

$$
\text { ع - منزلة السنة في الدين: الحسين سعيد، د . ت، ع). }
$$

القرآن الكريم هو الأصل الأول للدين،

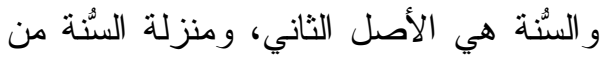
القرآن أنها مبيِّنه وشَارحة له تُقصل مُجْمله،

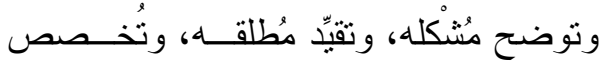

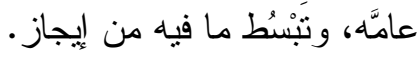
ولقد أجمع فقهــاء المـسلمين قـديماً وحديثًا على الاحتجاج بها وعدِّها المــصدر

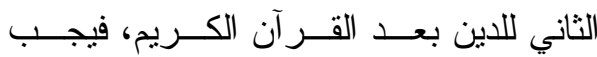

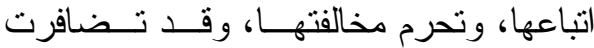
الأدلة القطعية على ذلك، فأوجب الله سبحانه

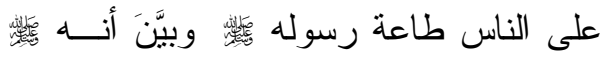
هو المبيِّن لما أنزل من القرآن، وذلك بعد أن عصمه من الخطأ والهوى في كل أمر مــن

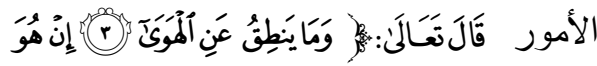

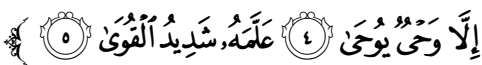
[النجم:r-0] ـ كما عصمه من الناس حسين

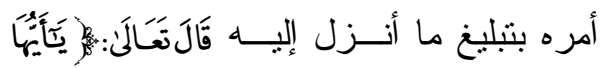

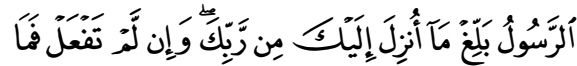

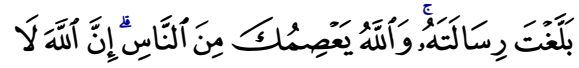

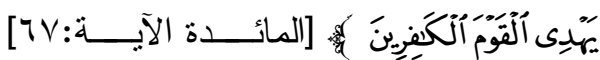

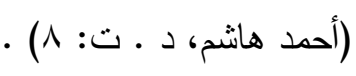

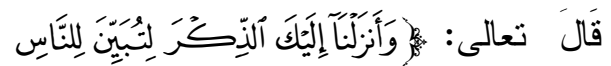

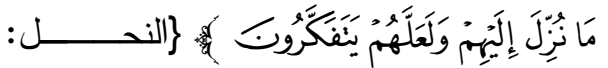

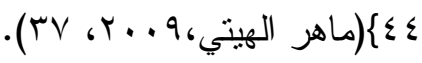
ومن ثمّ فالحديث النبــوي الــشريف

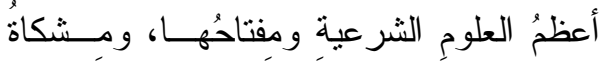

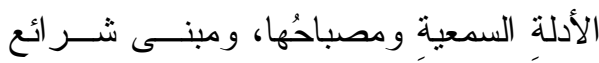

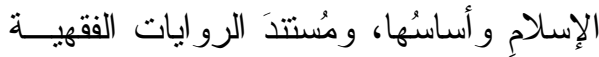

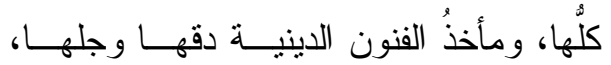
و أسوةُ جملة الأحكام و أساسُها، وقاعدةُ جميع

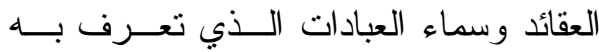
جو امع الكلم وتتفجر منه ينابيع الحكم، ولو لاه لقال مَنْ شُاء ما شـاء(إبر اهيم أبـــو إبـــحاق،

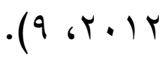
r- أنواع السنة النبوية: السنة النبوية على أنواع: سنة قوليه، وســنة فعلية، وسنة تقريرية:

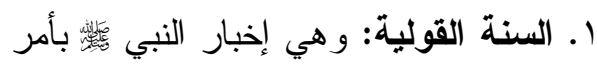

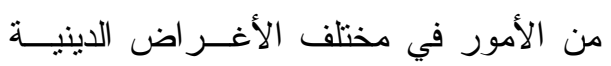
و الدنيوية. r ـ السنة الفعلية: وهي أن يفعل النبـي

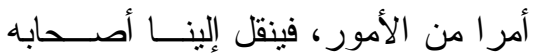
كيفية ذلك الفعل، كوضوئه، وصــلاته بهم، وحجه، وما إلى ذلك.

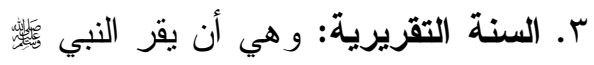

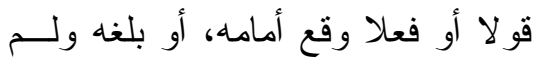

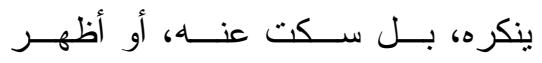


يؤدي إلى خلل في التواصل، و الذي قد ينتج عنه مشكلات لها عو اقب سيئة (محمد داود،

$$
\text { . (1) ، Y... }
$$

$$
\text { r- مفهوم التحليل الدلالي: }
$$

التحليل هو : الفتح و الحل ويعني تفكيك

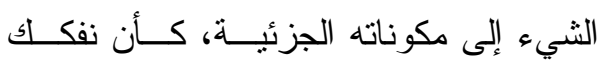

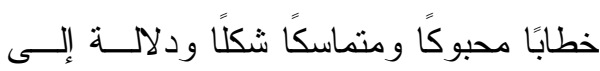
بنيات جزئية صغرى وكبرى فاعلة ومتفاعلة داخلية وخارجية، لمعرفة مرجعيات الخطاب

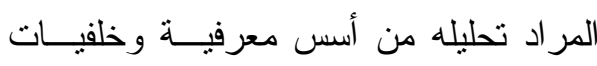
أيدولوجية وأطر نظرية ساهمت في تخلقــه منه

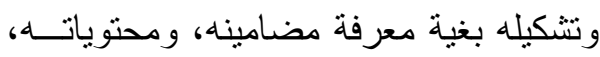

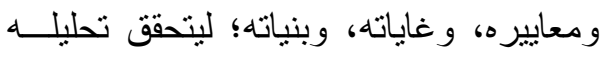

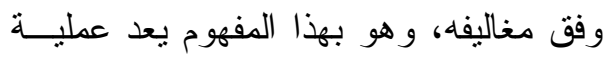

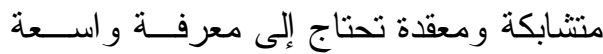
وعقول مدركة في تخصصها لأجل الــتحكم

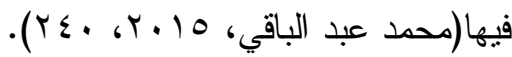
كما أثنار إير اهيم حشيش إلى عمليــة تحليل النص بأنَّا: عملية تعني تفكيك النص النص

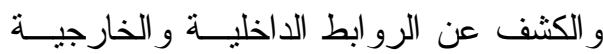
التي تربط بين عناصره، ثم إعادة ربط هــــه العناصر بصورة إبداعية (إبر اهيم حسشيش،

$$
\cdot(1 \cdot \Lambda \cdot 4 \cdot 1)
$$

\section{ويعرف التحليل الالالي فـي البحـث}

الحالي بأنه: العملية التي يتم فيها تتاول ألفاظ

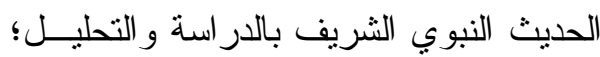

ثالثا - التحليـل الـدلالي ودوره في تنميـة الفهـم

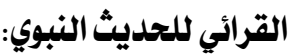
تتاول هذا العنصر (التعريف بالدلالــة،

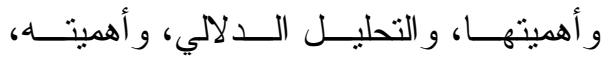
ومباحث الدلالة). 1- التعريف بعلم الدلالة: وعلم الدِّلالة يعرَّف بأنَّه: العلم الــذي

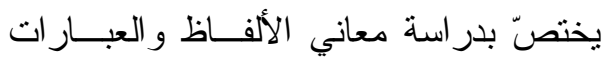

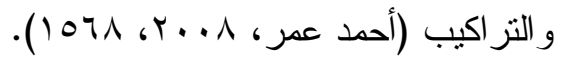
وخلاصة ما ســبق أنَّ مفهــوم علـم الدلالة يتحدد في وجود علاقة بـين شـيئين متلازمين إذا ذكر أحدهما اســــــى نظيــره الآخر ، ألا و هما الدال و المدلول. r - أهمية الالالة: تمتاز اللغة العربية بدقة متتاهية فـي

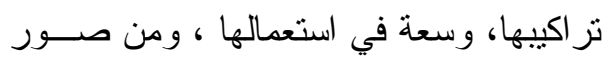

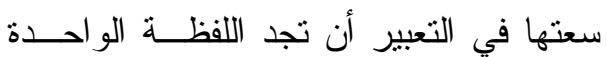
تحتمل أكثر من معنى، وقد يأتي بها المــتكلم لأجل أن يجمع المعاني كلها بأوجز أسلوب، فهو يوجز في التعبير ويوسع من دلالته. و المعرفة بالألفاظ المفردة هي الخطوة الأولى في فهم الكلام، فدلالة الألفــاظ أمـــر يتصل بجو انب حياتتا المتعـددة و التواصـلـل بمستوياته المختلفة بين الأفراد و الجماعــات

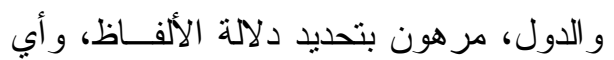
خلل في تحديد دلالة الألفاظ المستعملة بينهم 


$$
\text { لتعرثف دلالة أو معنى أي لفظ فيها، وما بين - مباحث علم الالالة: }
$$

اللغة نظام من الكلمات ذات طبيعــة

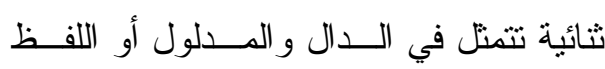

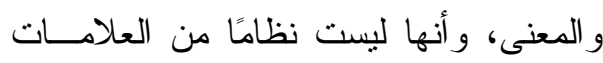

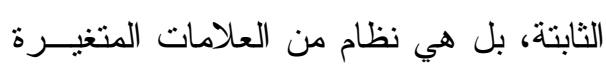

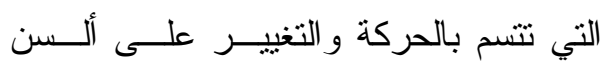

مستعمليها.

وما دامت اللغة نظامًا من العلامــات

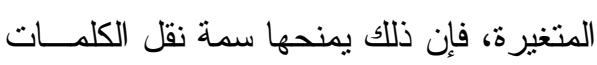

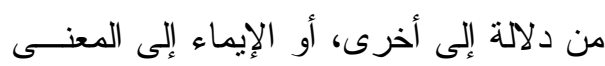

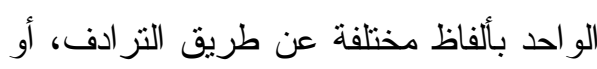
التعبير باللفظ الواحد عن المعـاني المتعـددة

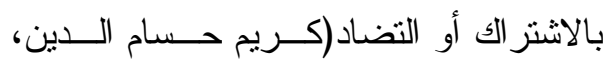

$$
\text { . (Y^ז ، Y...) }
$$

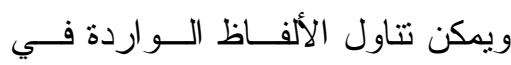

الحديث النبوي الثريف بالدراسة و التحليـلـل من خلال التعرف على المباحث الدلالية التي

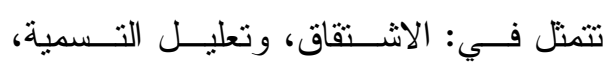
و الاثتر الك اللفظي، و التضاد و ألفاظ الأضداد،

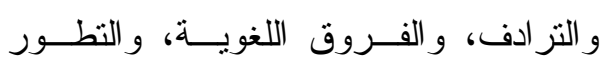

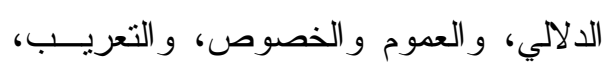

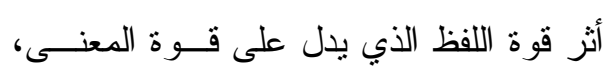
و أثر ها في تتمية الفهر القرائي للحديث النبوي

$$
\text { الثريف. }
$$

$$
\text { أ - الاشتقاق: }
$$

يمكن تعريفه بأنه: "اســتـداث كلمــة

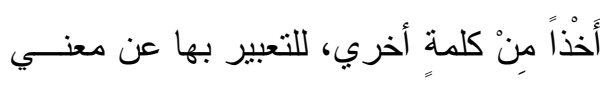

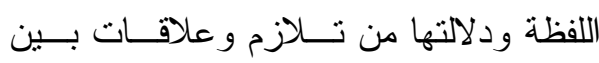

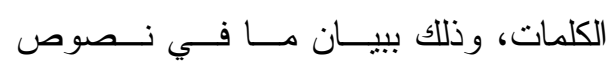
الأحاديث النبوية من اشتقاق، أو تز ادف، أو لون

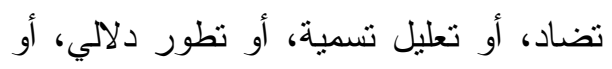
فروق، و غير ها من مباحث علم الدلالة. ع - أهمية التحليل الدلالي:

إنَّ تحليل اللفظة هو المدخل الأساسي للاخول إلى عمق النص، وجوهره، و الوسيلة

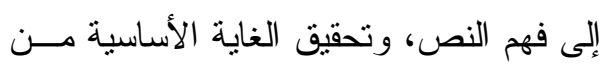

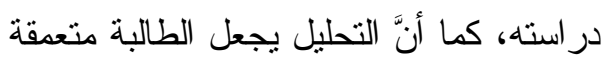

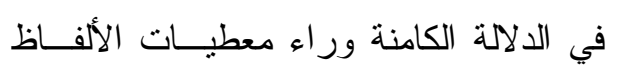
و التزر اكيب.

ويرى عمار سـاس(997 199، TYY).

أنَّ التحليل ذو قيمة كبرى في العمل الأدبـي

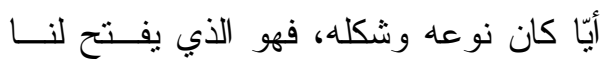

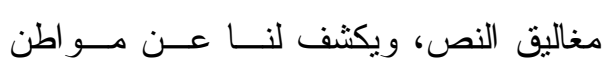
جمالية مستترة، ويبين لنا طريقة بديع نسقه، وليكاف

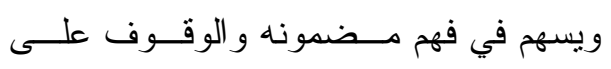
سماته.

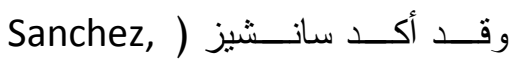
2009,9 أنَّ التحليل يكسب الطالب القـدرة على القز اءة الصحيحة للنـــصوص الأدبيـــة،

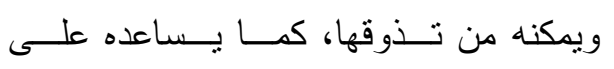
استخر اج المعنى الجمالي للـــص، و والقــدرة على قر اءة ما ور اء السطور . 
الاثتقاق لوجود رابطة معنوية بين المسـأخوذ و المأخوذ منه؛ وهي الرفعة في كل. ب- تعليل التسمية: يقصد بتعليل التسمية: "أن يكون فـي

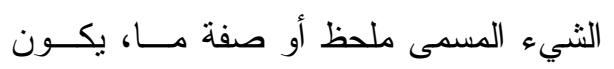

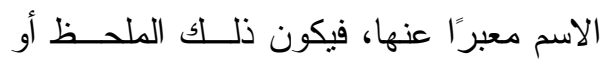

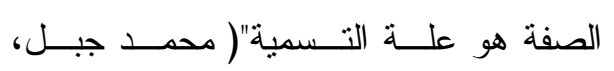
. (ะ ، 199 .

هذا وقد ورد تعليـلـل التـسمية فــي

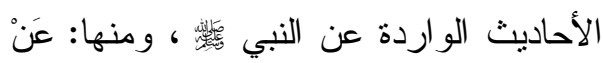

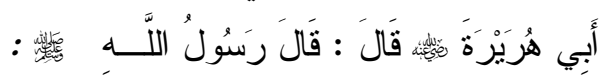

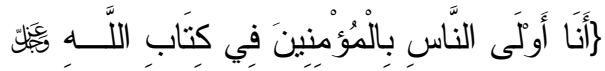

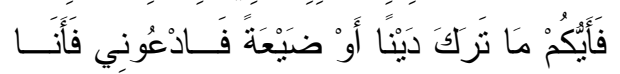

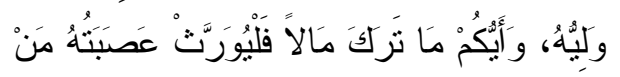
كَانَ (1)

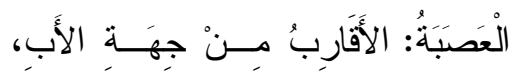

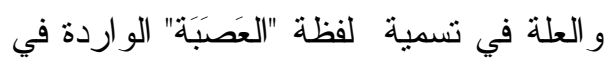

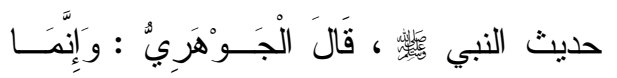

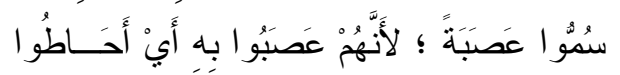

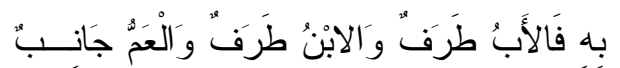

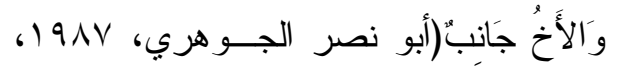
.(1)

(r) أخرجه مسلم في صحيحه، كتاب: الإيمان، باب: بيان نقصان الإيمان بالمعاصي ونفيه عن المتلبس

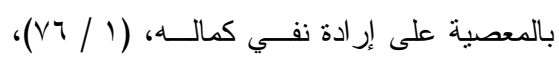
حديث رقم: (OV).
جديد يناسب المعني الحرفيَّ للكلمة المـأخوذ

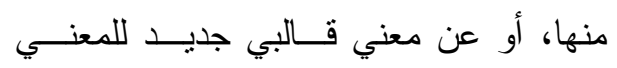

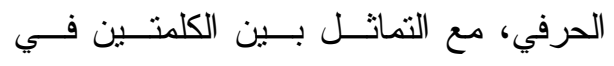

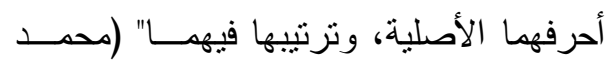
جبل،r ( • r، • (1). فالاشتقاق هو توليد كلمة جديدة مسن

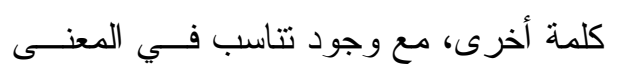

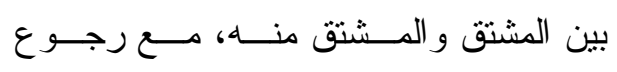

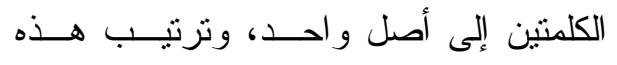

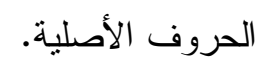
ومن ألفاظ الاشتقاق التي وردت فـي

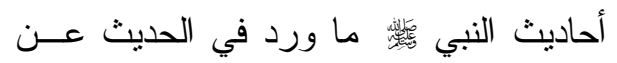

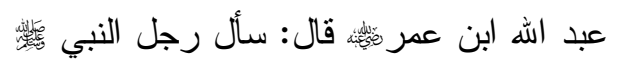

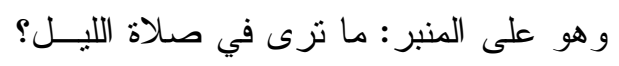

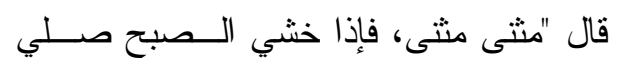
واحدة فأوترت له ما صلّي، وأنه كان يقول: "اجعلو آخر صلاتونتكم

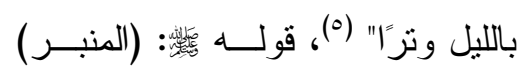
مشتق من النبر وهو الارتفاع (أبو الحسـن وتسن

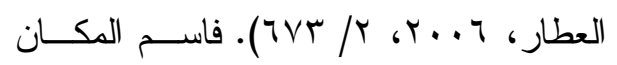
(المنبر) وهو حسي مشتق من المصدر (النبر) بمعنى ارتفاع الصوت وهو هو حسي، وقد وقع من الصني (1) أخرجه البخاري في صحيحه، كتاب: المـساجد،

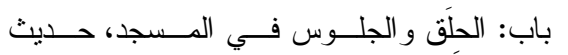

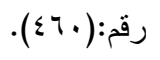


ضد الحياة، و القوة ضد الــضـعف، ويجمــع على الأضداد.

الظاهرة الثانية- ألفـــاظ الأضـــداد:

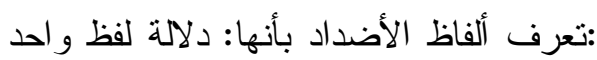
على معنيين منضادين، أو هو أن بُطلق اللفظُ

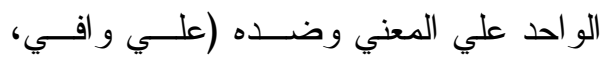

$$
\text { () ( } 1 \wedge \text { ، Y... V }
$$

ومن الأمتلة التي ورد فيها لفظ يحمل

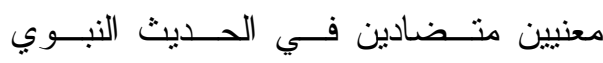
و الثريف، ما ورد في البخاري عَـنْن أَبْسي

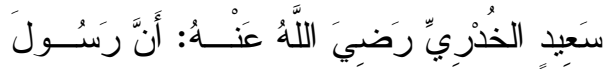

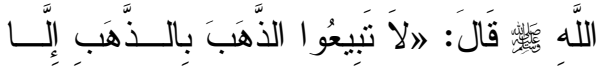

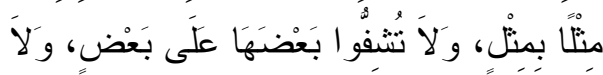

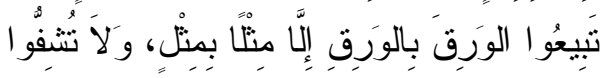

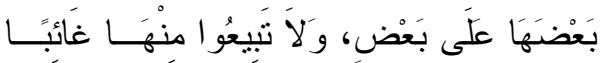

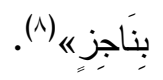

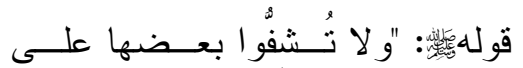

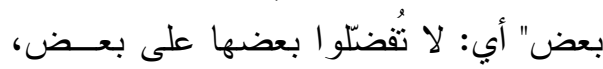

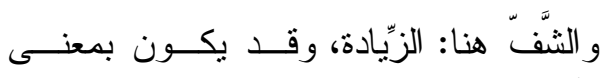

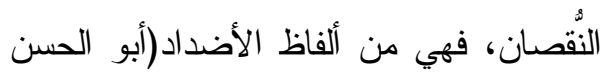

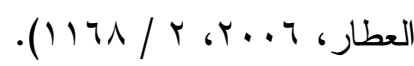

ج - المشترك اللفظي:

يعرف المشترك اللفظي بأنه: " اللفـــ

الو احد الدال على معنيين مختلفين فأكثر دلالة على السواء عند أهل تلك اللغة (جلال الدين

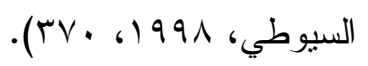

ومن الألفاظ التي ورد فيها اشــتر الك

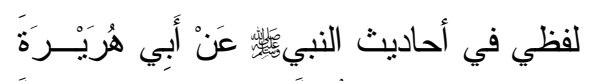

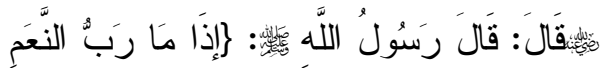

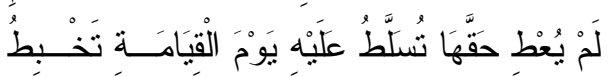

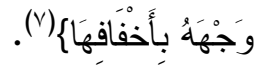
قولهَ

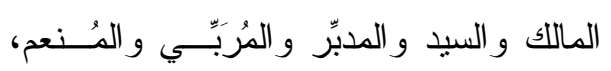

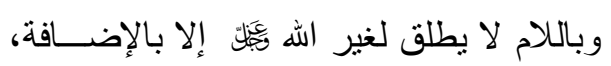

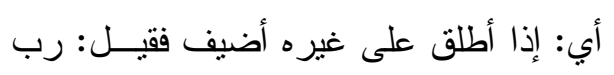

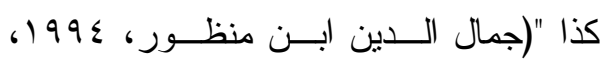

د - التضاد و ألفاظ الأضد (د:

الظاهرة الأولى - التضاد: يُعرَّف الضد

بأنَّهَ كل شيء ضاد شيئًا، فالحق ضد البـ الباطل، و الموت

(1) أخرجه البخاري في صحيحه، كتهـاب: الحيـلـ،

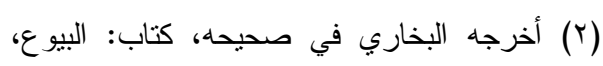

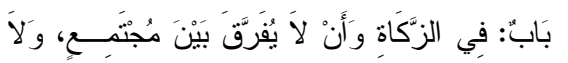

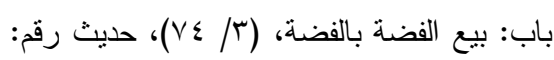

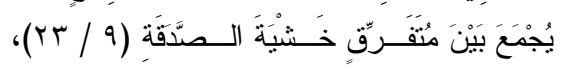

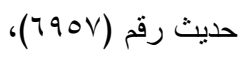


و القاف أصيل صحيح يدل على تمييز وتزييل

$$
\text { هـ - التر ادف: }
$$

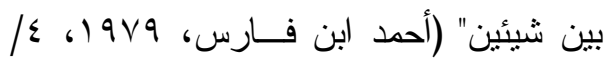

كما يُقصد بالفروق في التفسير وعلوم

القر آن: بيان أوجه الاختلاف فــي اللفـــ أو

التز ادف هو : الألفاظ المفــردةُ الدالــــة

علي شيء و واحد، باعتبـــارٍ و احـــد، فــي أبيٍ

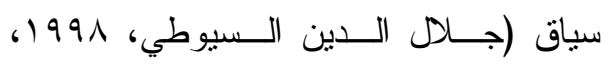

المعنى، أو الحكم بــين الأثــياء المتعلقـــة بالقرآن الكريم وعلومه التي يقع بينها اشتباه

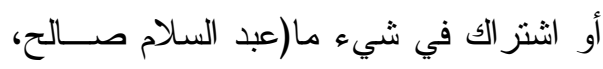

$$
\text { . ror ، r. I) }
$$

إذاً يقصد بالفروف الدلالية : التمييـز

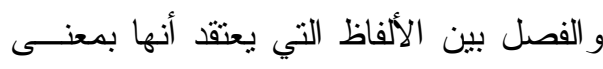

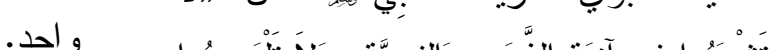

أو هو : دلالة عدة ألفاظ على معنـى

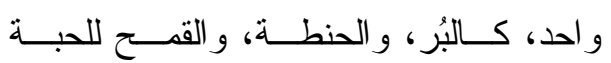

المعروفة، و الأسد، و الليث، و الهزبر للحيوان ولهن ولهن

$$
\text { المفترس (إبر اهيم نجا، و } 9 \text { (1، } 9 \text { ـ (1). }
$$

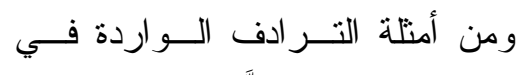

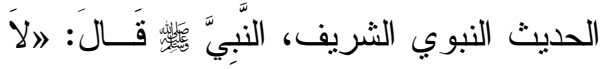

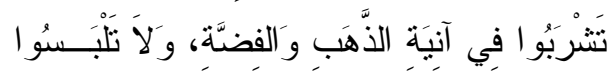

هذا وقد وردت الفروق الدلالية فـي

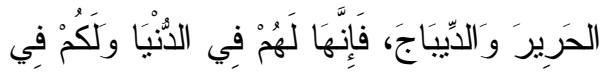

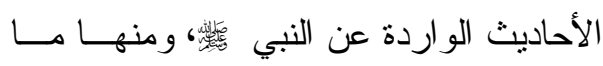

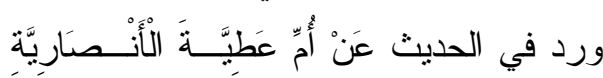

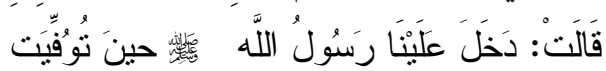

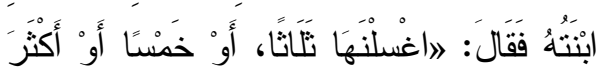

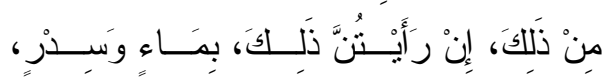

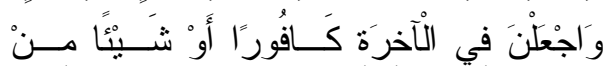

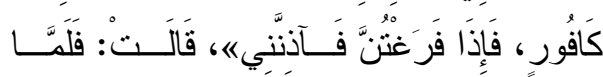

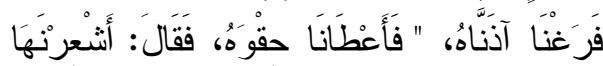

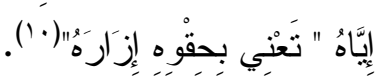

(1) أخرجه البخاري في صحيحه، كتاب: الجنـائز ، (1) أخرجه البخاري في صحيحه، كتاب: الأَتَْــربَّة،

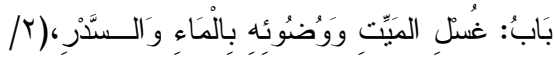

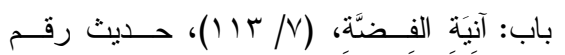

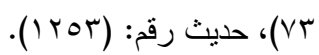


مستصرخًا مستتجداً يدعو الناس إلى إغاثثه،

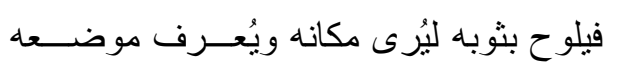

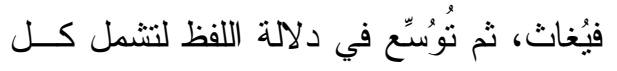

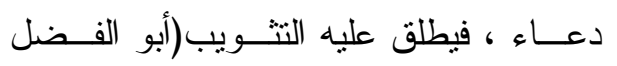

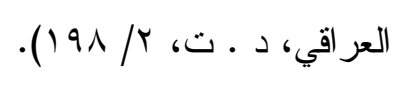
ح- العموم و الخصوص:

أولاً - العموم:"العـــام البــاقي علــي ولـي

عمومه، و هو : ما وضع عاما واستعمل عاما"

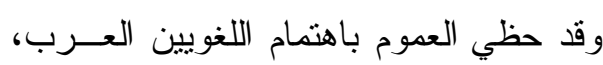
وكانو ا يستخدمون في تقسير معنـــاه كلمــة:

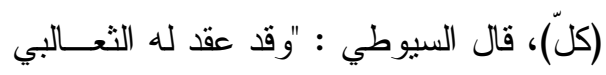

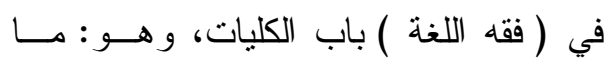

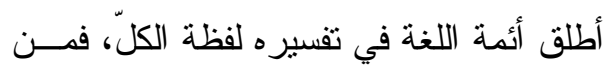

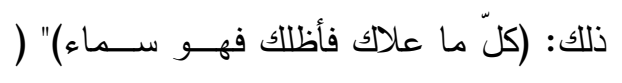
جلال الدين السيوطي، 1991 1، (سب).

ومن الألفاظ العامة الواردة في حديث النبي

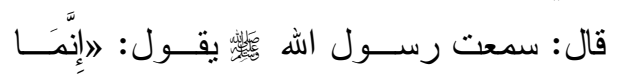

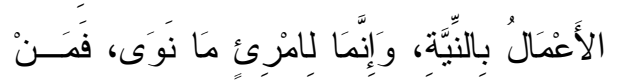

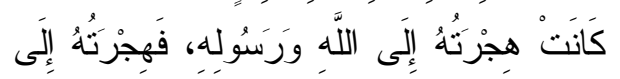

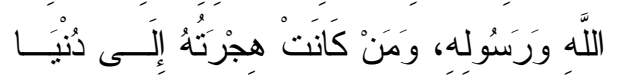

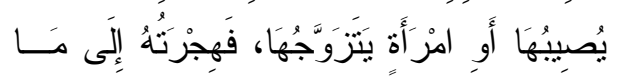

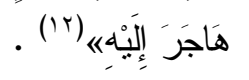

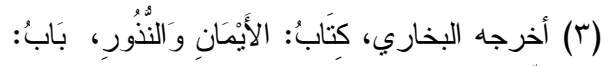

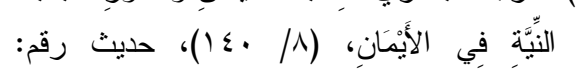
(74199)

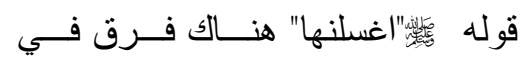

المعنى بين كلمة (الغُسل) بالضم و (الغَـسل) فئس)

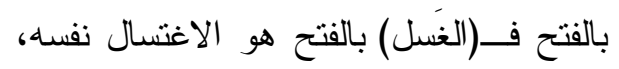

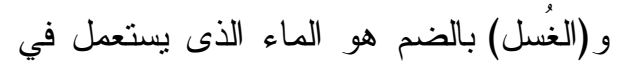

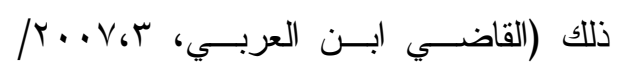
.$(0.4$

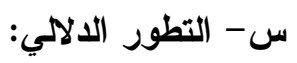
يعرف التطور الالالمي بأنـــه: التغيــر التدريجي الذي يصيب دلالات الألفاظ بمرور بانه

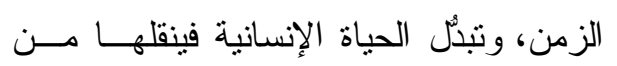

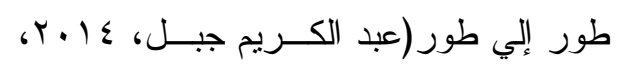
. ( $\varepsilon$. ومن الألفاظ التي تطورت دلالتها في

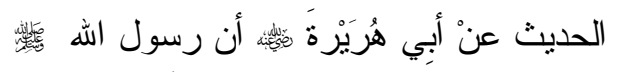

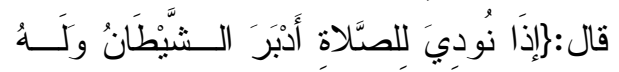

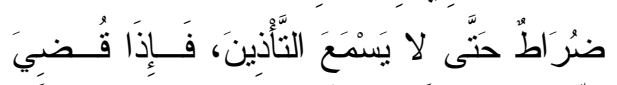

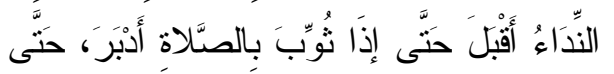

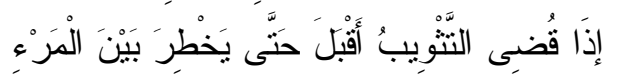

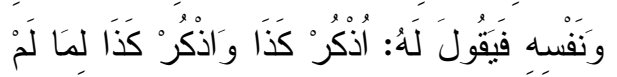

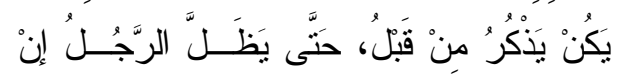

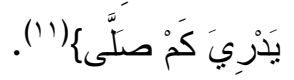

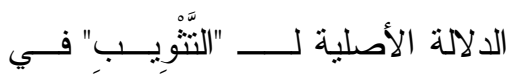
حديث النبي

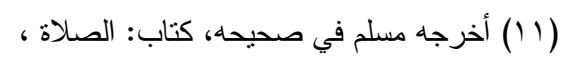

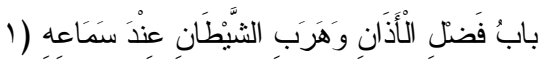

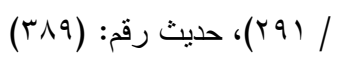




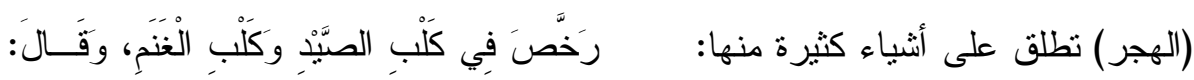

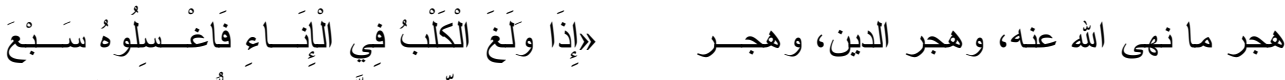

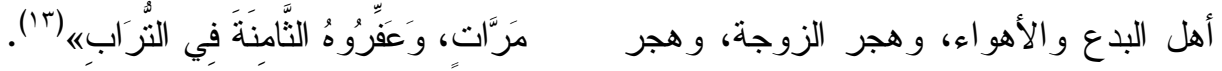
لفظ "الولوغ" الوارد في حديث النبــي

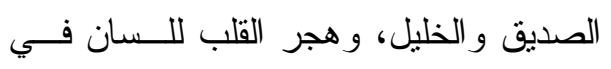

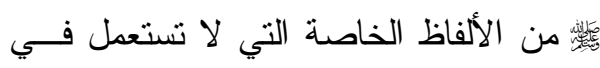

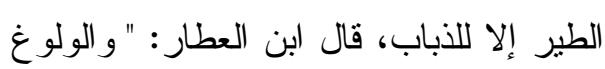

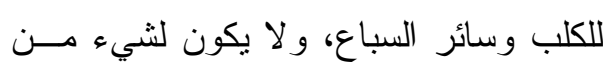
الذكر ، وهجر الوطن، و الهجرتين المعروفتين

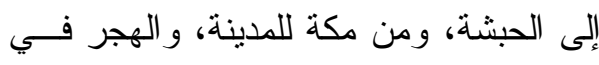
الصوم وهو اعنزال النكاح.

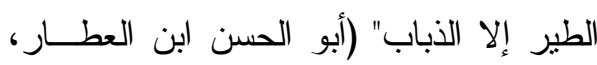

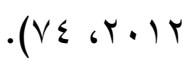

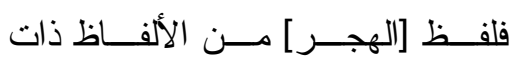
الدلالات العامة التي تطلق على هجر وترك

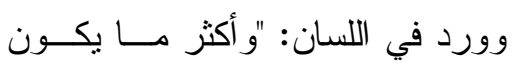
الوطن وغيره.

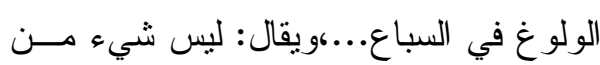
ثانياً - الخصـــــوص: الخصوص في

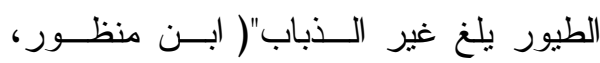
اللغة : الإفر اد، وهو خلاف العموم، قال ابن .$(\leqslant 7 \cdot / 1$. 1991

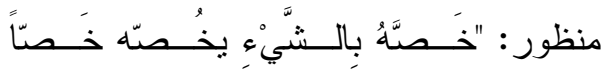

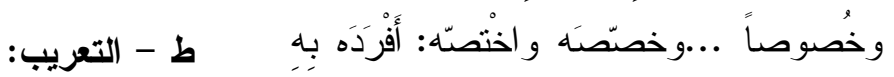
الإنسان اجتماعي بطبعه، واجتماعيته

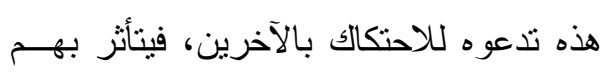

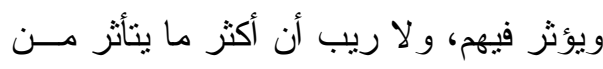
جر اء ذللك الاحتكاك هو اللغة.

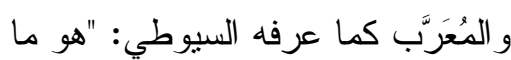
استعمله العَرَب من الألفاظ الموضوبر عة لمعانٍ

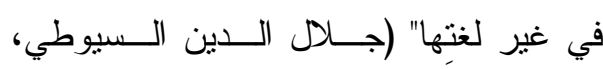
.(Y) . 1991

(1) أخرجه مسلم في صحيحه، كتاب: الطهارة، باب:

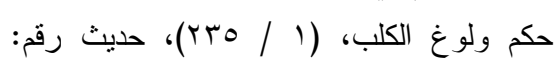

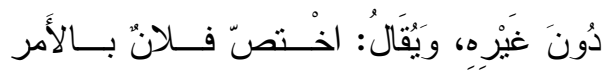

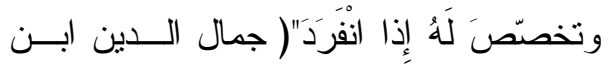

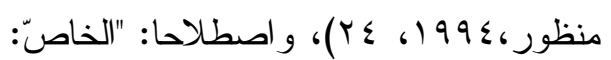

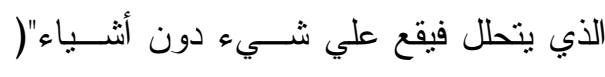

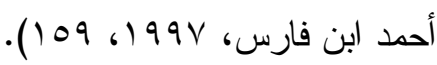
أو هو :" ما يُعَبِّر عن مُعَسَيِّن منميـز

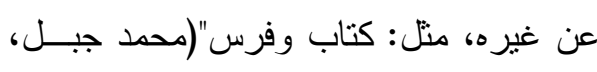
. (1 1 1 6 . . . O ومن الألفاظ الخاصـــة الـــواردة فــي الحديث النبوي الشريف، عن عَبْــــ الله عَـنـن

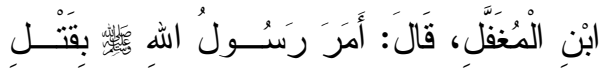

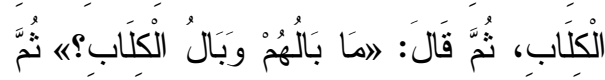
.(rA.) 
ومن الألفاظ التي دلَّت على قوة اللفظ

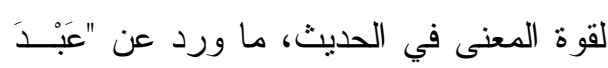

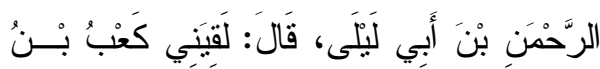

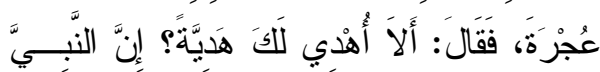
كَّ

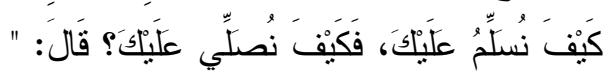

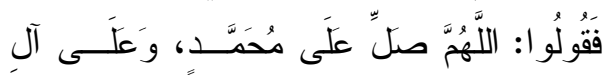

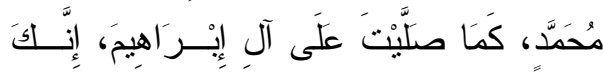

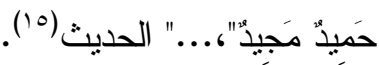

قوله له

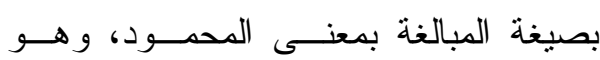

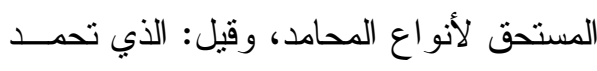
أفعاله، ومجيد: مبالغة في الماجد، وهو الذي

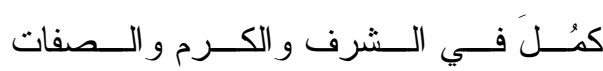

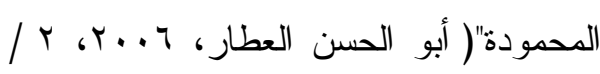
. (7) - 7).

كما دلت كلمتا (حميد ومجيد) علــى المبالغة، فهما كلمتان على وزن (فعيل)، ذلك الوزن من أوز ان صيخ المبالغة التـي تـدل على التكثير ، و الحميد: فعيل من الْحَمَد بِمَنْى إنى

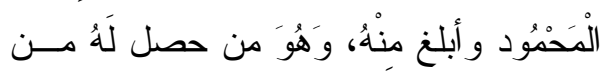

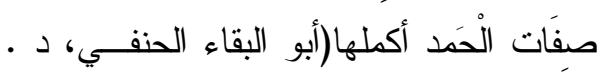

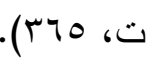

(1) أخرجه البخاري في صحيحه، كتاب: الدعوات،

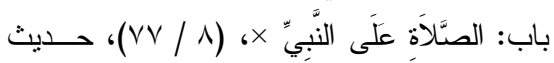

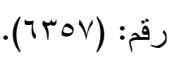

ومن الألفاظ المعربة التي وردت فـي

هدي النبي

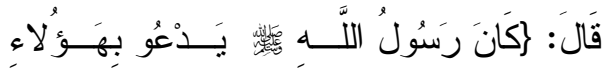

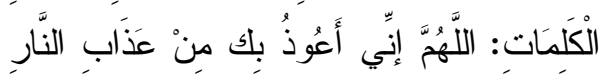

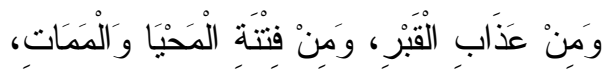

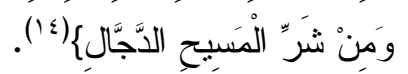

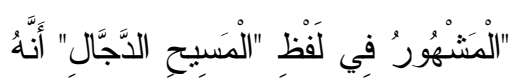

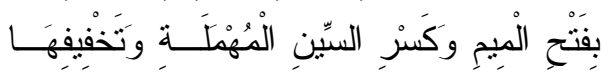

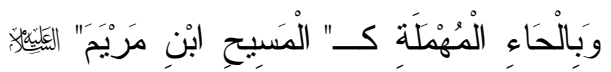

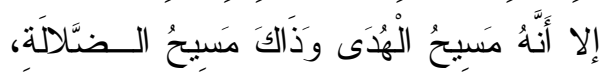

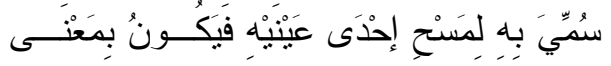

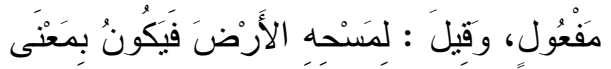

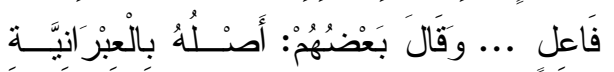

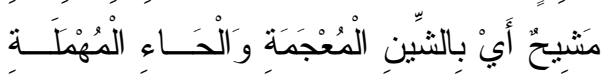

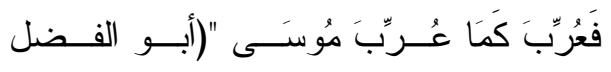

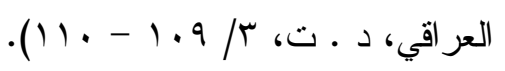
ك - قوة اللفظ الذي يدل على قوة المعنى: يقصد بقوة اللفظ: "ما يطر أ عليه مــن

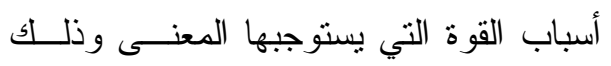
كالزيادة للتضعيف أو ناء الافتعال أو الزيادة

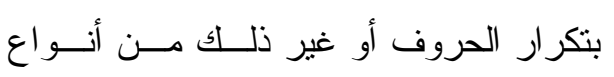

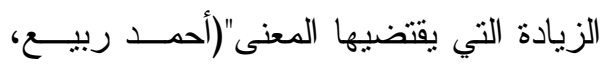
. (0. (Y) أخرجه البخاري في صحيحه، كتاب: الدعوات،

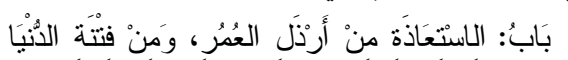

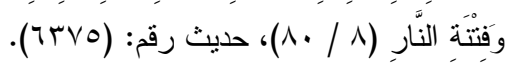


- كتب المناهج وطــرق تــدريس اللغــة العربية، والتزبية الدينية الإســلامية،

$$
\text { و العلوم الثر عية. }
$$

- البحوث و الدراسات السابقة التي اهتمت

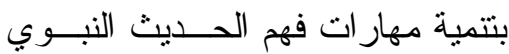
الثريف، منل دراسة: أحمد الأسطل (1 (1 • rم)، ودر اسة صالحة الرويلـي

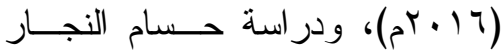
(Y. V)

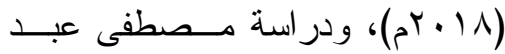

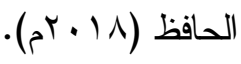

- البحوث و الدراسات السابقة التي اهتمت

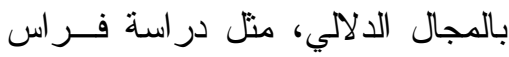

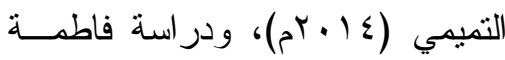

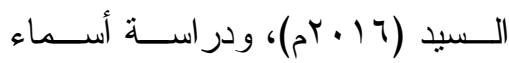

$$
\text { الثحات (T ( • r م). }
$$

- استطلاع آراء بعض المتخصصين في تدريس الحديث الثريف من أســاتذة

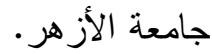

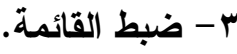

لضبط قائمة المهار ات، و التأكد مـنـ صدقها، تم عرضها على عدد من المحكمين

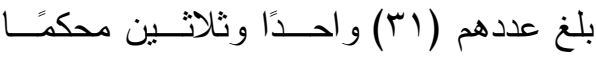
متخصصين في مجال اللغة العربية وطر ائق تدريسها، و المتخصصين في تدريس الحديث

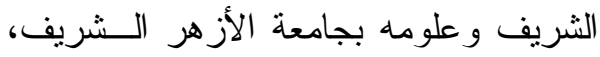

أما "مجيد "فهو أكثر في الصفة مـن

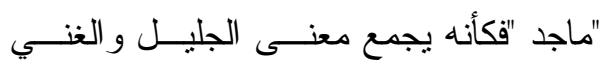

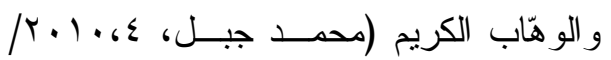
(r.

\section{المحور الثالث: خطوات البحث وإجراياته:}

أولًا - إعداد قائمة بمهارات الفهم القرائي للحديث النبوي الثريف لاى طالبات

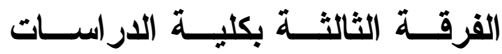
الإسلامية و العربية بنات المنصورة. 1 - تحديد الههف من القائمة. الهدف الرئيسي من إعداد هذه القائمة هو تحديد مهار ات الفهم القرائسي للحــديث النبوي الثريف المناسبة لدى طالبات الفرقة بكلية الدراسات الإسلامية و العربيــة بنــات

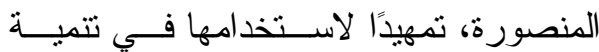

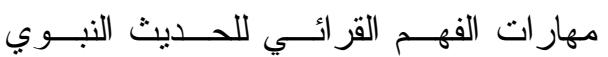
الثريف في ضوء التحليل الدلالي. r - تحديد مصادر بناء القائمة. تََّّ بناء قائمة المهـــار ات مــن خــلهل الرجوع إلى المصادر التالية: - قر اءة وتحليل الأهداف العامة والخاصة لتعلــيم الحــديث النبـــوي الــشريف ونه بالمر احل المختلفة (إعدادي - ثـانوي - جامعي). 


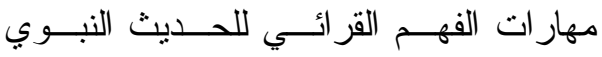

$$
\begin{aligned}
& \text { وطلب من السادة المحكمين الاطـــلاع علــى } \\
& \text { الشريف، ولمعرفة مدى تحقق أهداف البحث. } \\
& \text { r - مصادر إعداد أسئلة الاختبار. } \\
& \text { اعتمد الباحث فــي إعــــاده للاختبـــار } \\
& \text { الحالي على مجموعة من المصادر ، منها: } \\
& \text { - القائمة النهائية لمهارات الفهم القرائسي } \\
& \text { للحديث النبوي الثريف التــي توصــل } \\
& \text { إليها الباحث. } \\
& \text { - الاختبار ات التي نم إعدادها في مجــال } \\
& \text { تتمية الفهم للحديث النبوي الثريف. } \\
& \text { - الاطلاع علــى البحــــث و الدر اســات } \\
& \text { السابقة التي قامت بإعداد اختبار ات فــي لإني } \\
& \text { اللغة العربية بصفة عامــة، والحـديث } \\
& \text { النبوي الثريف بصفة خاصة. } \\
& \text { - مر اجعة كتب الحديث النبوي الـشريف } \\
& \text { المقررة على طالبات الفرقة الثالثة بكلية } \\
& \text { الدراسات الإسلامية و العربية، وما جاء }
\end{aligned}
$$

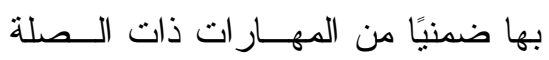

$$
\begin{aligned}
& \text { بالتحليل الدلالي. } \\
& \text { ب- صلاحية الــصورة الأوليــة للاختبــار } \\
& \text { (الصدق الظاهري للاختبار): }
\end{aligned}
$$

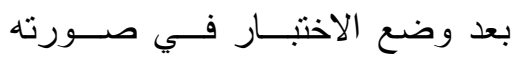

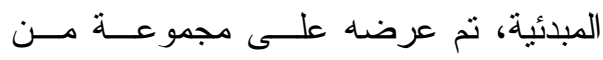

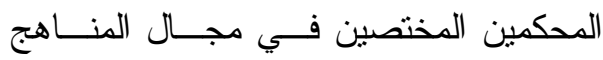

$$
\begin{aligned}
& \text { وطرق تدريس اللغة العربية و العلوم الثرعية }
\end{aligned}
$$

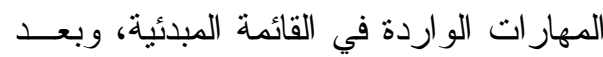

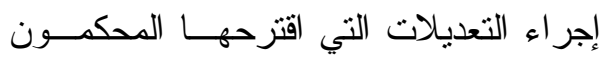

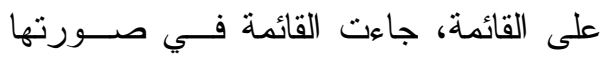

$$
\begin{aligned}
& \text { النهائية مكونة من (1) (1) ثماني عشرة مهارة }
\end{aligned}
$$

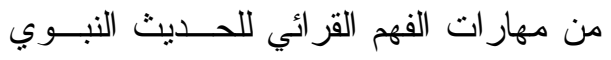

$$
\begin{aligned}
& \text { الشريف المناسبة لطالبات الفرقة الثالثة شعبة } \\
& \text { اللغة العربية بكليــة الدراســات الإســـامية }
\end{aligned}
$$

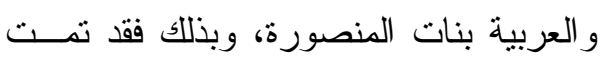

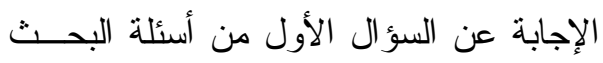

$$
\begin{aligned}
& \text { الذي ينص على: - الإنه } \\
& \text { س: ما مهارات الفهم القرائي للحديث }
\end{aligned}
$$

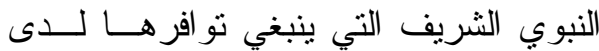

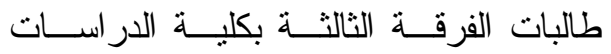

$$
\begin{aligned}
& \text { الإسلامية و العربية للبنات بالمنصورة؛ بهو } \\
& \text { ثانيًا - إعداد اختبار مهارات الفهم القرائسي } \\
& \text { للحديث النبوي الشريف. } \\
& 1 \text { - تحديد الهذف من الاختبار. } \\
& \text { استهدف الاختبار قياس مدى تمكـن }
\end{aligned}
$$

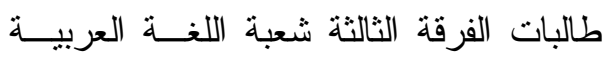

$$
\begin{aligned}
& \text { بكلية الدراسات الإسلامية و العربية للبنـات }
\end{aligned}
$$




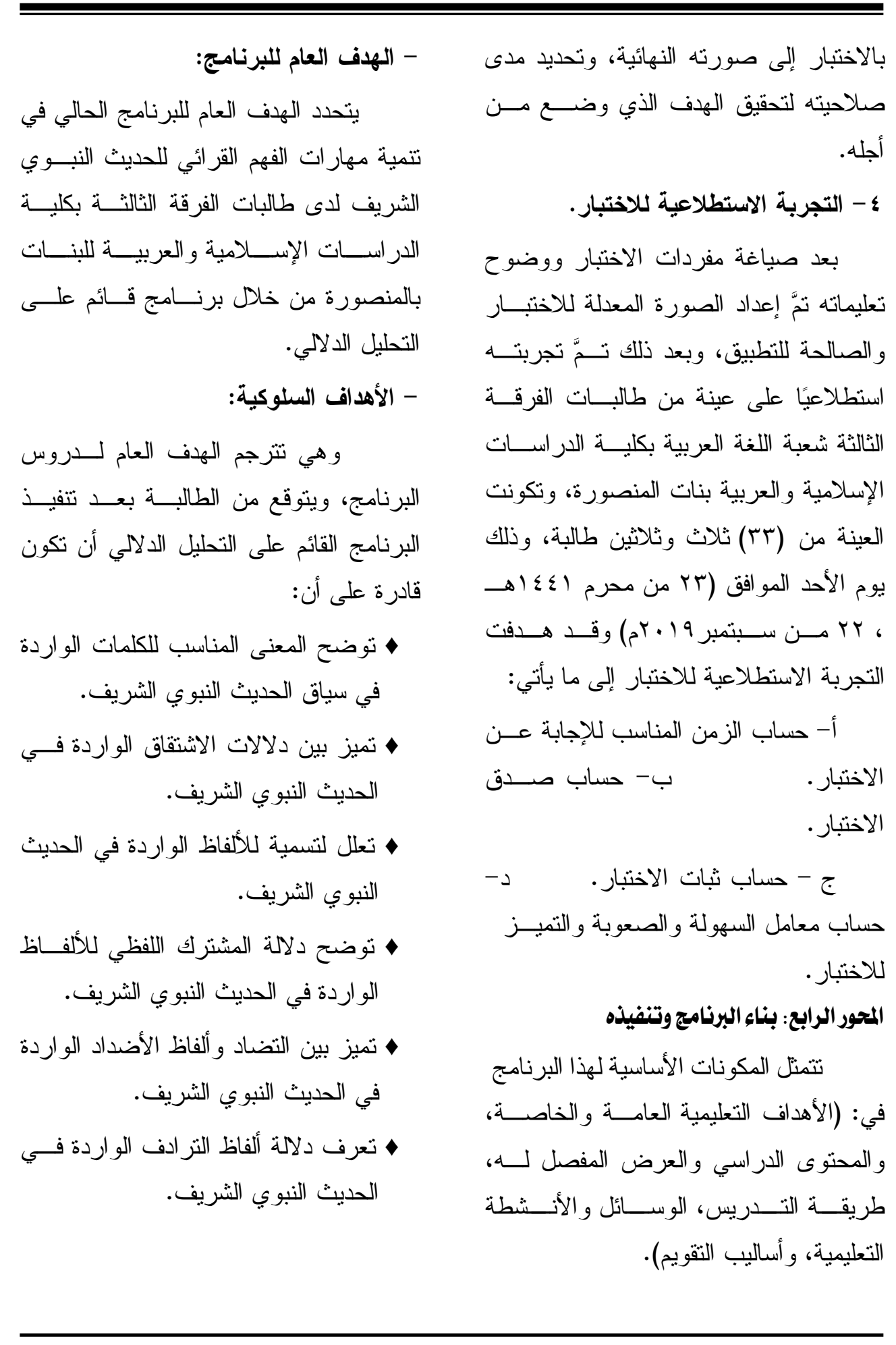


تشتتبط الدروس المستفادة من الحــديث

$$
\text { النبوي الثريف. }
$$

اختيار المحتوى التعليمي للبرنامج:

يتمثل محتوى البرنامج في مجموعــة

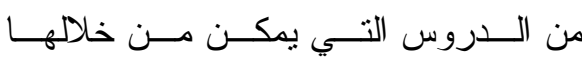

تتميـــة مهـــار ات الفهـــم القر ائسـي للحـديث

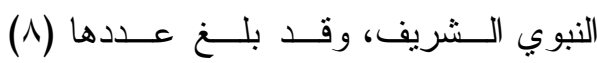

ثمانية دروس، كل درس يشتمل على حديث

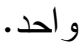

\section{دليل المعلم لتدريس البرنامج.}

تم إعدادا دليل المعلم وفق الخطوات الآتية: 1- تحديد الهدف من الاليل.

r- تحديد محتوى دليل المعلم.

ب- صلاحية الصورة الأوليــة لــليل

$$
\text { المعلم. }
$$

تم إعداد دليل المعلم بهــدف تــدريب

المعلم على تدريس البرنامج المقترح القــائم

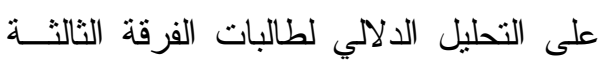
شعبة اللغة العربية بكلية الدراسات الإسلامية

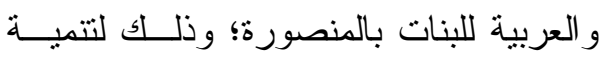

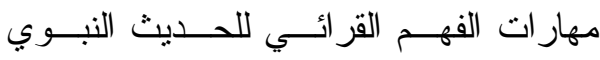

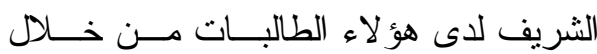
تحليل الألفاظ الواردة في الحــديث النبــوي

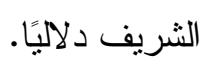

تميز بين الفــروق الدالاليــة لـــعض

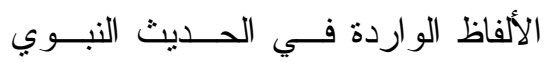

$$
\text { الثريف. }
$$

• نشرح التطور الدلالي للألفاظ الــواردة

$$
\text { في الحديث النبوي الثريف. }
$$

•تميز بين الدلالات العامسـة والخاصــة

لبعض الألفاظ الـــواردة فـــي الحــديث

$$
\text { النبوي الثريف. }
$$

• ثنيّن دلالة الألفاظ المُعربّة الواردة فــي

$$
\text { الحديث النبوي الشريف. }
$$

• نستتنج أثز قوة اللفظ في دلالتــه علـى

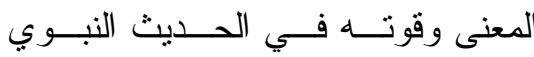

$$
\text { الثريف. }
$$

• نوضح أثز التوجيه الإعر ابـي لمعنـى

$$
\text { الحديث النبوي الثريف. }
$$

ثانوضح الصور البلاغية الـــواردة فـــي

$$
\text { الحديث النبوي الثريف. }
$$

• نوضح الدلالات الإيحائية لبعض الألفاظ

$$
\text { الو اردة في الحديث النبوي الثريف. }
$$

• تستتتج الفكرة الرئيسة التي يدور حولها

$$
\text { الحديث النبوي الثريف. }
$$

• تستنبط الأحكام الفقهيــة الـــواردة فـــي

$$
\text { الحديث النبوي الثريف. }
$$

• تلخص المعنى الإجمالي للحديث النبوي

$$
\text { الثريف. }
$$


بكلية الدراسات الإسلامية و العربية للبنـات بالمنصورة، وذلك من خلال تطبيق اختبـار

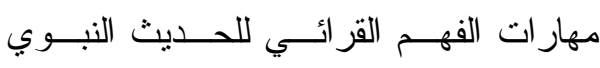
الشريف (تطبيقًا قبليًا) ثم تطبيــق البرنــامج المقترح، ثم تطبيق الاختبار نفـسه (تطبيقًا بعديًا) ثم المقارنة بين نتائج الاختبار القبلــي لـي

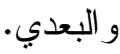
وتمثلت إجر اءات التطبيق فيما يلي: أ- تطبيق اختبار مهارات الفهـــم القرائسـي للحديث النبوي الثريف تطبيقًا قبليًا. طُبِّق اختبار مهار ات الفهـم القرائـي للحديث النبوي الثريف (قبليًا) على عينة من طالبات الفرقة الثالثة شعبة اللغـــة العربيــة بكلية الدراسات الإسلامية و العربية للبنــات بالمنصورة، و الذي بلغ عددهن (·r) ثلاثين طالبة؛ لتحديد مستوى أداء الطالبات في تلأك المهارات وذللك في يوم الاثثين المو افق (ع من محرم إ§§اهـ - س r من سـبتمبر $\cdot\left(a^{2} \cdot 19\right.$

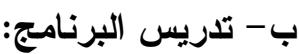
بعد الانتهـــــــــن التطبيــق القبالـي لاختبار مهار ات الفهم القرائي للحديث النبوي

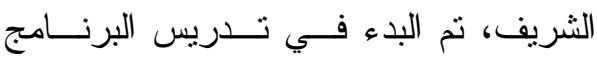
المقترح القائم على التحليل الدلالي، وتم البدء

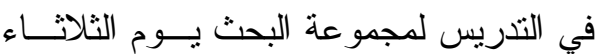

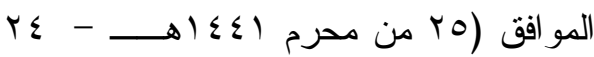

\section{ץ - تحديد محتوى دليل المعلم:}

اثتتمل دليل المعلم علـى العناصــر

الآتية (المقدمة، التعريف بالبرنامج، و أهدافه،

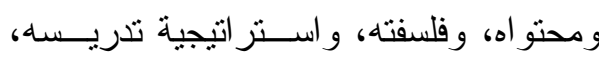
و إجــر اءات طريقـــة تدريـسـه، و الوســـائل التعليمية و الأنشطة المستخدمة فيه، وأساليب التقويم). - صلاحية الصورة الأولية لاليل المعلم: بعد الانتهاء من إعداد الدروس التـي

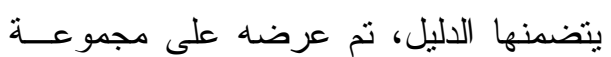

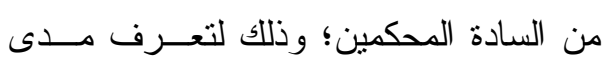
قدرته على تحقيق الأهداف المنشودة.

\section{وصف العينة:}

تمّ اختيار عينة البحث من طالبـات

الفرقة الثالثة شـــبة اللغـــة العربيــة بكليـــة الدر اســـات الإســــلامية و العربيــــة للبنــــات

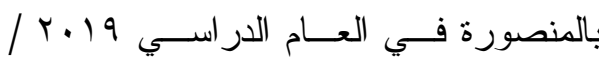

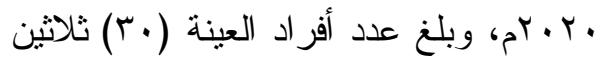

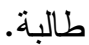
- إجر اءات تطبيق البحث: اعتمد البحث الحالي علــي التـصميم التجريبي ذي المجموعة الواحدة، ونمَّ في هذا التصميم تحديد مدى فاعلية البرنامج المقترح القائم على التحليل الدلالي في تتمية مهار ات

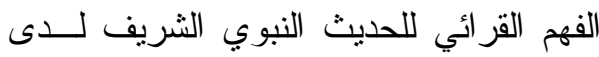
طالبات الفرقة الثالثة شعبة اللغـــة العربيــة 
الشريف لدى طالبات الفرقة الثالتــة شــــبة اللغة لعربية بكليــة الدر اســات الإســلامية

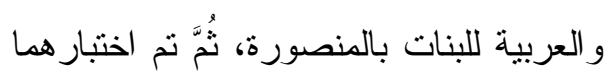
كما يلي:

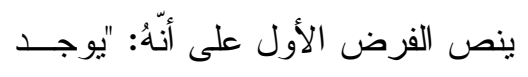

فرق ذو دلالة إحصائية عند مستوى دلالــــة

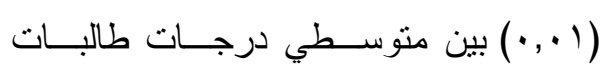

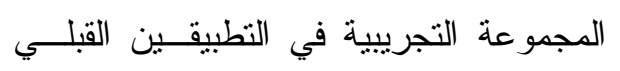

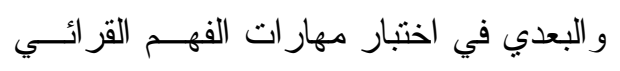

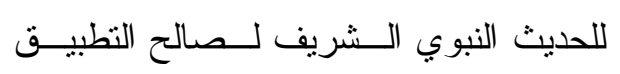

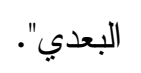

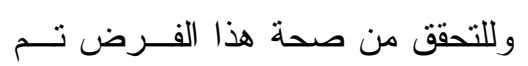

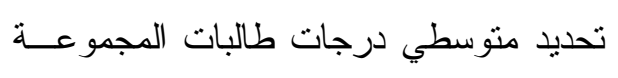

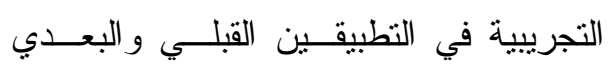
لاختبار مهار ات الفهم القرائي للحديث النبوي ولئي الثريف، و الانحر اف المعياري لكل منهمــا، وتحديد الفرق بين المتوسطين، وحساب قيمة

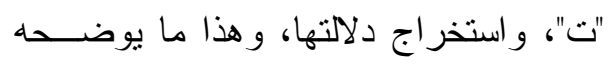

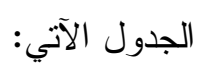

من سبتمبر 9 ـ ـ rم) و انتهى يـوم الثلاتــاء

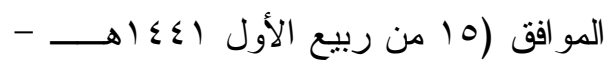
rا من نوفمبر 9 ( • بrم). جـ - التطبيق البعدي لاختبــار مهــارات الفهم القرائي للحديث النبوي الثريف بعد الانتهاء من تــدريس البرنــامج

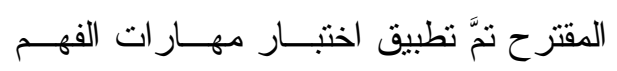
القرائي للحديث النبوي الشريف (بعديًّ) على تلى

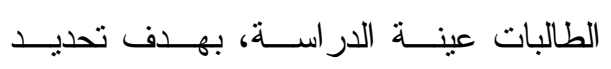

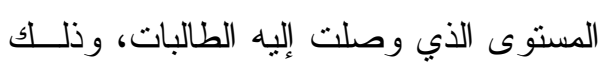

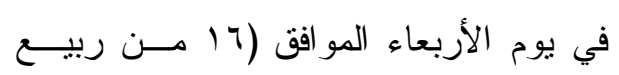

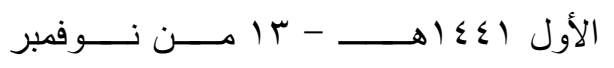

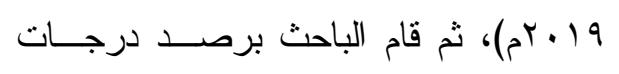

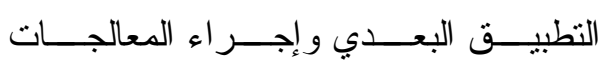

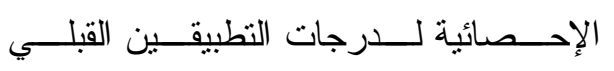
و البعدي. المحور الخامس-نتائج البحث: صاغ الباحث فرضين لتحديد فاعليــة

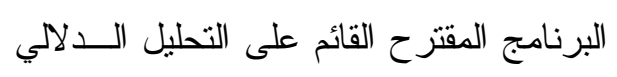
لتتمية مهار ات الفهم القرائي للحديث النبــوي لفئري 
قيمة "ت" للفرق بين متوسطي درجات طالبات المجموعة التجريبية في التطبيقين القبلي و البعدي لاختبار مهارات الفهم القرائي للديث النبوي الثريف ككل وفى أبعاده الفرعية

\begin{tabular}{|c|c|c|c|c|c|c|c|c|}
\hline الالالة & درجة الحرية & $\begin{array}{c}\text { قيمة "ت } \\
T\end{array}$ & الالمعرافى افع & المتوسط & العدد & التطبيق & \multicolumn{2}{|l|}{ المهارة } \\
\hline \multirow{2}{*}{$\cdot,+1$} & \multirow{2}{*}{ rq } & \multirow{2}{*}{$1 \leq, \wedge-$} &., $0 Y 1$ & $1, \cdot v$ & $r$ & قبلي & \multirow{2}{*}{ الأولى } & \multirow{16}{*}{ 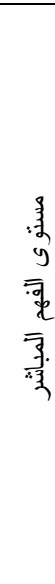 } \\
\hline & & & $\cdot, r \leq 4$ & $r, \wedge V$ & $r$. & بعدى & & \\
\hline \multirow{2}{*}{$\cdot, \cdot 1$} & \multirow{2}{*}{ rq } & \multirow{2}{*}{ rv,q- } &.,$\leqslant 9$. & $\cdot, \mu V$ & $r$. & قبلى & \multirow{2}{*}{ الثانية } & \\
\hline & & & $\cdot, r \circ \leq$ & r,qu & $r$. & بعدى & & \\
\hline \multirow{2}{*}{$\cdot, \cdot 1$} & \multirow{2}{*}{ rq } & \multirow{2}{*}{$1 \wedge, \cdot-$} &., $7 \wedge 1$ &., $0 r$ & $r$. & قبلي & \multirow{2}{*}{ الثالثة } & \\
\hline & & & $\cdot, r \cdot 0$ & $r, q$. & $r$ & بعدى & & \\
\hline \multirow{2}{*}{$\cdot, \cdot 1$} & \multirow{2}{*}{ rq } & \multirow{2}{*}{$1 \wedge, r-$} & $\cdot, \Delta \wedge r$ & $1, \cdot V$ & $r$ & قبّلى & \multirow{2}{*}{ الر ابعة } & \\
\hline & & & $\cdot, \ldots$ & $r, \ldots$ & $r$ & بعدى & & \\
\hline \multirow{2}{*}{$\cdot, \cdot 1$} & \multirow{2}{*}{ rq } & \multirow{2}{*}{$1 v, 1-$} & $\cdot, Y \wedge r$ &., 0 . & $r$ & قبلى & \multirow{2}{*}{ الخامسة } & \\
\hline & & & $\cdot, r \cdot 0$ & $r, q$. & $r$ & بعدى & & \\
\hline, 1 & $\mathrm{rq}$ & $101-$ &., $7 \wedge 1$ &., $0 r$ & $r$. & قبلي & 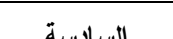 & \\
\hline 01 & 1. & 10,1 & $\cdot, r \vee q$ & $r, \wedge r$ & $r$ & بعدى & المسدلمش & \\
\hline. .1 & pq & $r \cdot, \varepsilon-$ & $\cdot, 7 \wedge 1$ & $\cdot, \leqslant V$ & $r$ & قبلى & السيابعة & \\
\hline , & & & $\cdot, \cdots$ & $r, \ldots$ & $r$ & بعدى & الستبع & \\
\hline., 1 & rq & $0, \varepsilon-$ & $1, r \wedge r$ & $\varepsilon, \circ H$ & $r$ & قبلى & مستوى الفهم & \\
\hline, 1 & 17 & . & $\cdot, \wedge I V$ & $r \cdot, \leqslant r$ & $r$. & بعدى & المباشر ككل & \\
\hline 1,1 & ra & $1 \mathrm{r}-1$ & $\cdot, V 1 \leq$ & $1, r$ & $r$ & قبلى & الثامنة & \\
\hline ( & 1 & 足 & $\cdots, \ldots$ & $r, \ldots$ & $r$ & بعدى & & \\
\hline. .1 & rq & $15.9-$ & $\cdot, \mathrm{V} \wedge \mathrm{A}$ & $\cdot, \leqslant r$ & $r$ & قبلي & التاسعة & \\
\hline , & & & $\cdot, \varepsilon \cdot V$ & $r, \Lambda$. & $r$ & بعدى & & \\
\hline$\cdot, .1$ & rq & $1 \leq, 9-$ &., 790 & $1, \cdots$ & $r$ & قبلى & العاشرة & \\
\hline , & 1. & 16,1 & $\cdot, 1 \wedge r$ & $Y, 9 V$ & $r$. & بعدى & & 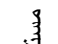 \\
\hline - 1 & $r g$ & $14 .-$ & .,VH. & $1,1 \%$ & $r$. & قبلي & الحادية عشرة & :- \\
\hline , & 1. & 16 & $\cdot, \ldots$ & $r, \ldots$ & $r$ & بعدى & & 司 \\
\hline. .1 & rq & I r. & $\cdot, \wedge 0$. & $1, \cdot r$ & $r$ & قبلى & الثانية عشرة & te \\
\hline , & & & $\cdot, Y \circ \leq$ & $r, q 4$ & $r$. & بعدى & & 习习 \\
\hline$\cdot, .1$ & rq & $q, r-$ &., 710 & $1,9 \mathrm{~V}$ & $r$. & قبلى & الثالثة عشرة & ओ: \\
\hline & & &,$\ldots$ & $r, \ldots$ & $r$ & بعدى & & \\
\hline 0.1 & ra & $190-$ & $\cdot, 7 \vee 0$ & $\cdot, 7$. & $r$. & قبلي & الر ابعة عشرة & \\
\hline , & 1 & 1,0 & $\cdot, \ldots$ & $r, \ldots$ & $r$ & بعدى & & \\
\hline. .1 & rq & rq, 1- & $1,9 \cdot r$ & $0,7 r$ & $r$ & قبلى & مستوى الفهم & \\
\hline ( & & &., 0 Oro & $1 \wedge, V$. & $r$ & بعدى & التذوقي ككل & \\
\hline. .1 & rq & $1,9-$ & $\cdot, \vee \vee 9 \leq$ & $1, v$. & $r$ & قبلى & الخامسة عشرة & \\
\hline , & & & $\cdot, \cdots$ & $r, \ldots$ & $r$ & بعدى & & in \\
\hline. .1 & rq & q. & $\cdot, 771$ & $1,7 V$ & $r$. & قبلى & السـادسة عشرة & \\
\hline , & & , & $\cdot, r \cdot 0$ & $r, 9$. & $r$ & بعدى & & 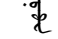 \\
\hline., 1 & rq & $1 \cdot, r-$ & $\cdot, \wedge 0$. & $1, r v$ & $r$. & قبلى & السابعة عشرة & $\bar{z}$ \\
\hline , & 17 & $1 \cdot 1$ & $\cdot, 1 \wedge r$ & r, qV & $r$. & بعدى & & 奉 \\
\hline., .1 & rq & $1 \cdot, r-$ & $\cdot, \wedge \bullet \wedge$ & $1, Y r$ & $r$. & قبلي & الثامنة عشرة & j; \\
\hline , & 1. & $1 ., 1$ &., 470 & $r, q r$ & $r$. & بعدى & & \\
\hline 1,1 & $r g$ & $119-$ & $1,7 \times 9$ & $0,9 V$ & $r$. & قبلي & مستوى الفهم & \\
\hline ו & 1. & Th, & $\cdot, \times 71$ & $11,1$. & $r$ & بعدى & الاستتتاجي ككل & \\
\hline., .1 & rq & $79,1-$ & $r, 74 r$ & $17,1 \%$ & $r$. & قبلي & الكلبة & d) \\
\hline ( & & & 1,rq & $0 \cdot, 94$ & $r$ & بعدى & & \\
\hline
\end{tabular}


على التحليل الـــلالمي لطالبــات المجموعــــة

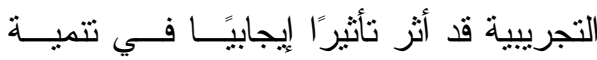
مهار ات الفهم القر ائي للحديث النبوي. ينص الفرض الثاني على أنّهُ: "يحةــــ البرنامج القائم على التحليل الدلالي فاعلية

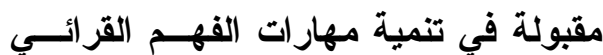
للحديث النبوي الثريف".

وللتحقق من صحة هـــا الفــرض تــم

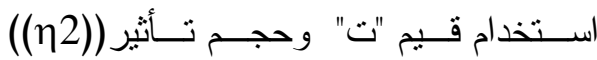

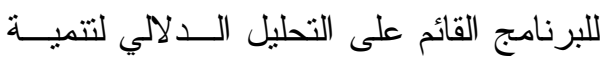

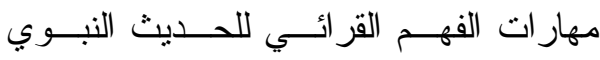
الثريف لــدى طالبــات كليــة الدراســات

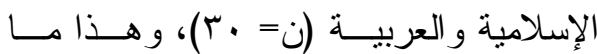

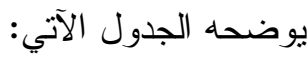

يتضح من الجــدول الــسابق وجــود

فروق دالة إحصائيًا بين متوسطي درجـات

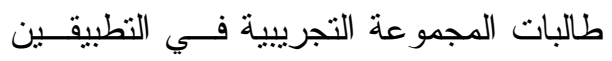
القبلي و البعدي في مستويات ومهار ات الفهر القر ائي للحديث النبوي الثريف لاى طالبات الفرقة الثالثة بكليـــة الدراســـات الإســلامية و العربية للبنات بالمنصورة، وفى الدرجة الكلية للاختبار لــصالح

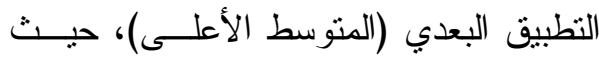

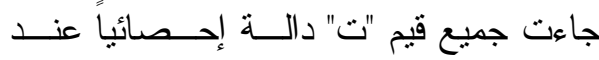
مستوى دلالة (0.01) ودرجة حرية (9 (؟). و هذا بــدل علــى تفــوق طالبــات المجموعة التجريبية فــي التطبيــق البعــدي لاختبار مهار ات الفهم القرائي للحديث النبوي الثريف؛ مما يعنى أن تدريس البرنامج القائم

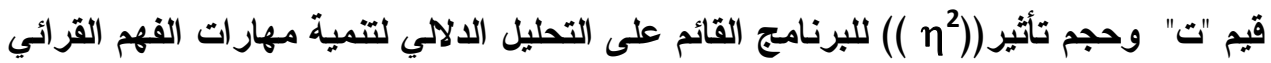
للحديث النبوي الشريف لاى طالبات كلية الارسات الإسلامية و العربية (ن = ب)

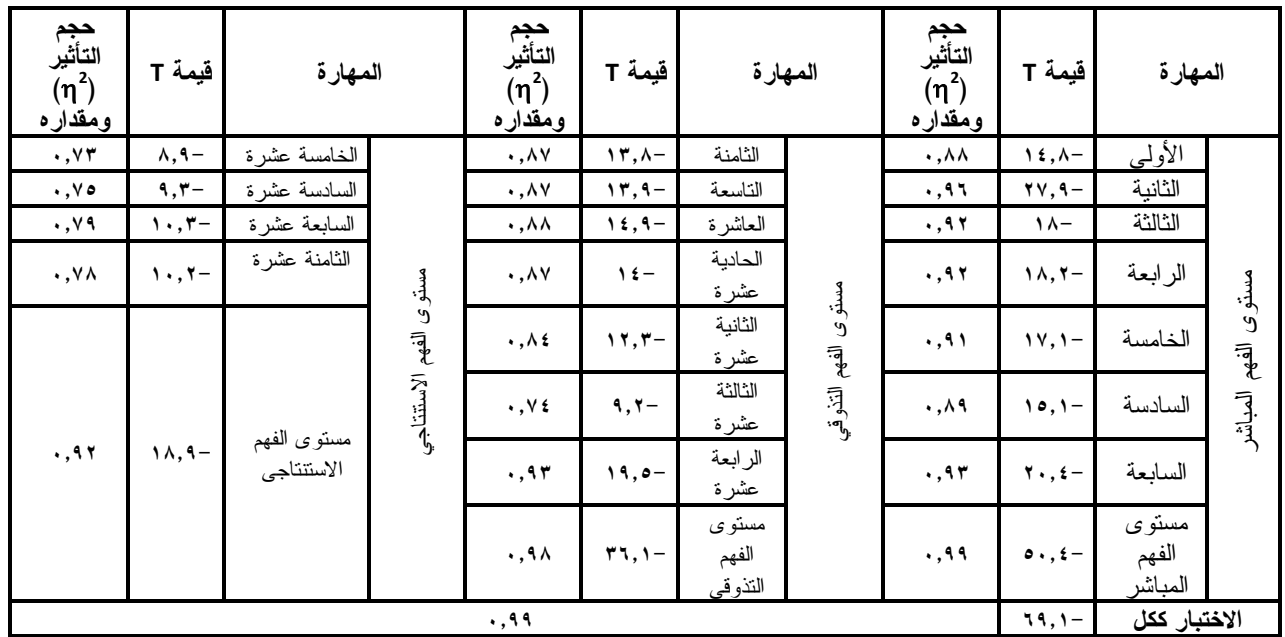


فاعلية عالية للبرنامج في تتمية مهار ات الفهم القرائي للحديث النبوي الثريف لاى طالبات الفرقة الثالثة - شعبة اللغة العربية - بكليــة

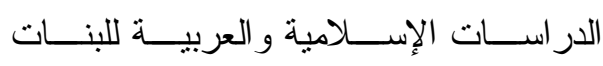
بالمنصورة.

ويرجع الباحسـث فاعليــة البرنــامج المقترح في نتمية مهار ات الفهـم القرائـي لئي

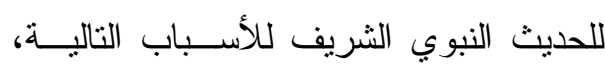
منها:

- الانطلاق في المحتوى من النــصوص

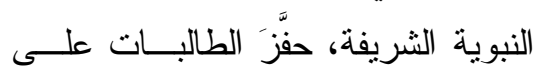

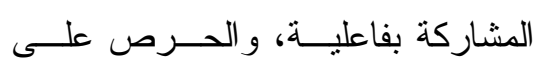
الإفادة من هذا البرنامج.

- المناقشتة و الحوار ؛ حيث اعتمد برنــامج البحث الحالي عليهما في التدريس؛ مما واعند بند أدى إلى وجود تفاعل نشط وإيجابي بين

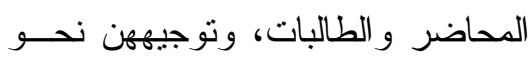

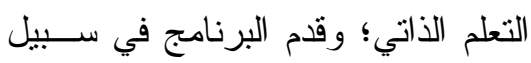

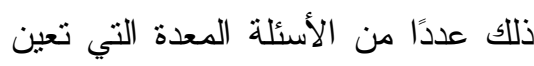

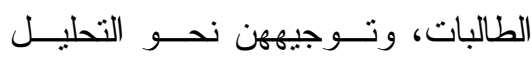

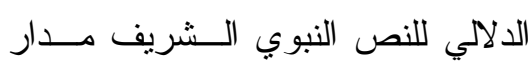
الدر اسة، وفهمه. - إثارة دافعيــة الطالبــات نحـــو تعلـــم

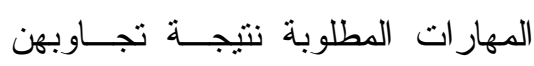
بالأسلوب الجديد المعتمد على الحـــوار

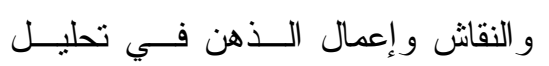

يتضح من نتائج الجدول الـسابق أن

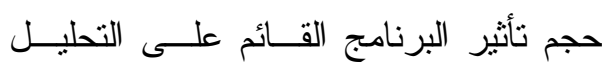

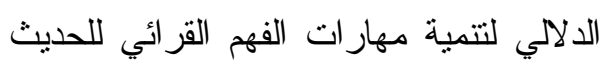
النبوي الثريف لاى طالبات الفرقـــة الثالثـــة شعبة اللغة العربية بكلية الدراسات الإسلامية

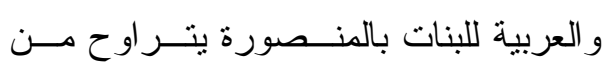

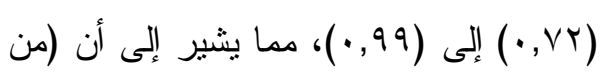

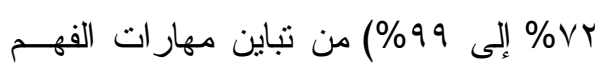
القرائي للحديث النبوي الشريف يرجع إلـى مئى

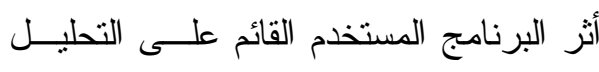

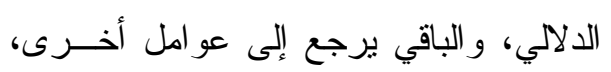

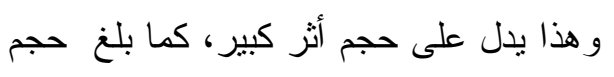
تأثثر البرنامج المستخدم على الدرجة الكليــة للاختبار (99, • ))، مما يشير إلى أن (99\%)

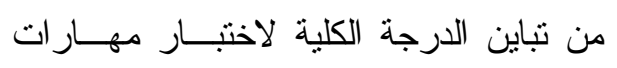

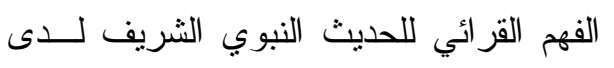

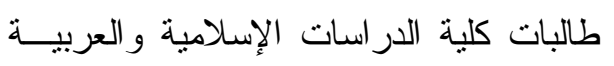
يرجع إلى أثز البرنامج المستخدم، و البـاقي لئي

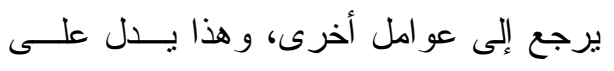
حجم أثز كبير •

\section{مناقشة نتائج البحث وتفسيرها:}

اتضح من عرض نتــائج البحـــث أن

هناك فروقًا ذات دلالة إحصائية بين مستوى من نئ لبن

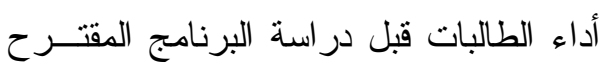

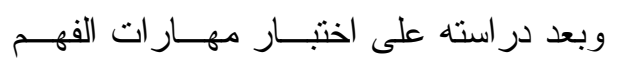

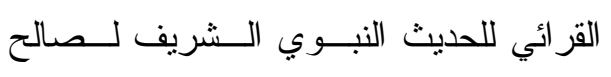
التطبيق البعدي، كما أنتبت نتــائج الاختبــار 
في الحديث النبوي الثريف، وتحديـــ

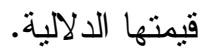

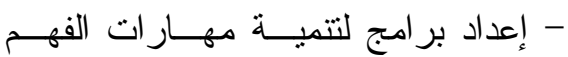
القرائي للحديث النبوي الثريف، وفهم دلالات الألفاظ النبوية لدى الطالبــات بالفرق الدر اسية المختلفة، وبما يتتاسب مع مستويات الطالبات بكل فرقة. - عقد دورات تدريبية لمعلمي ومعلمـات العلوم العربية و الـشرعية؛ لتـدريبهر على استخدام البرنامج المقترح القـائم على التحليل الدلالي وتوظيفه في تتمية مهار ات الفهم القرائي للحديث النبـــوي الثريف لــدى الطالبــات بالمر احـلـل

المختلفة.

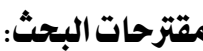

1- برنامج قائم على التحليل الدلالي لتتمية مهارات الفهم القرائي للنصوص القرآنية لاى طالبات كلية الدر اسات الإســلامية

$$
\text { و العربية. }
$$

r- برنامج قائم على التحليل الدلالي لتتمية مهارات الفهم القرائي للنصوص الدينية لاى طلاب المرحلة الثانوية الأزهرية. r- برنامج قائم على الفروق الدلالية لتتمية مهار ات الفهم القرائي للنصوص القر آنية لاى طالبات كلية الدراسات الإســلامية

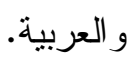

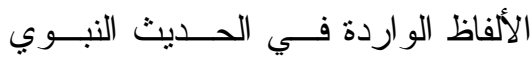

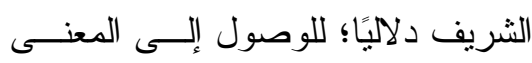

و الفهم الصحيح للنص النبوي الثريف.

- إفــساح البرنـــامج المجــال للإبــــاع و القدرات من خلال التدريبات المفتوحة

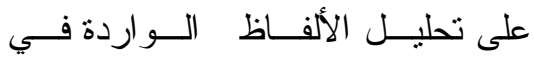
الأحاديـــث النبويـــة الــشريفة دلاليًّــا و الاستفادة منها في الوصول إلى المعنى الدقيق و الصحيح الذي يقتضيه السياق.

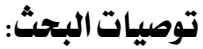

في ضوء ما توصل إليه البحث مـن

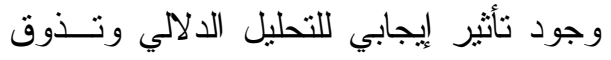
قيمته الدلالية في تتمية مهار ات الفهم القرائي للحديث النبوي الثريف، وفي تحسسين أداء الطالبات، فإنَّ البحث يوصي و اضعي مناهج التعليم الجامعي بإعادة تتظيم محتوى الحديث النبوي الثريف في ضوء الاتجاهات التربوية

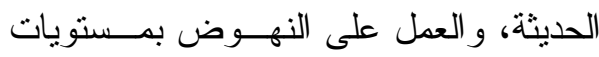

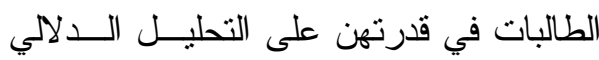
للألفاظ الواردة في الحديث النبوي الثريف، وذللك من خلص: - الاهتمام بوضع محتوى الحديث النبوي الشريف في ضوء التحليل الدلالي. - تزويد كتب الحديث النبــوي الــشريف بالتدريبات التي تقيس مستوى الطالبات في القدرة على تحليل الألفاظ الـــواردة 
النص في تتمية مهار ات التذوق الأدبـي لدى طلاب المرحلة الثانوية و اتجاهاتهر نحو النصوص الأدبية، رسالة دكتور اه، جامعة المنصورة، كلية التربية. ع - إير اهيم نجا (9V7 (1) ): اللهجات العربية، مصر ، مطبعة السعادة. 0- أبو البقـــاء الحنفــي (د ـ ت) : الكليــات

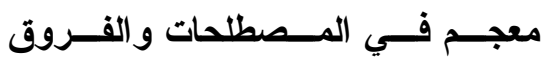
اللغوية، تحقيق: عدنان درويش و محمد المصري، بيروت، مؤسسة الرسالة. צ- أبــــو الحـــسن عــــلاء الـــدين بــنـن

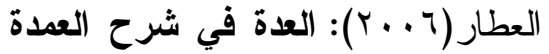
في أحاديث الأحكام، تحقيق: نظام محمد صالح يعقوبي، بيــروت، دار البـشائر

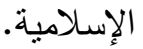

V- أحمد ابن فارس (999 1 )): الصاحبي في فقه اللغة العربيــة ومسـسائلها وســنـن فئن العرب في كلامها، الناشر : محمد علـي ومي ونسي

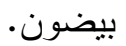

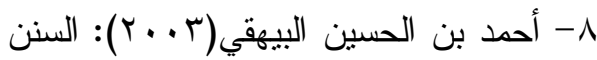
الكبرى، تحقيق: محمد عبد القادر عطا،

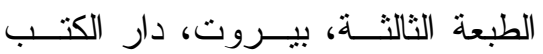
العلمية. - مان 9 - أحمد بن عمر بن إير اهيم بن هاثم (د . ت): كتابة السنة النبوية في عهر النبي

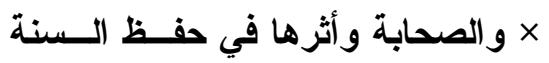

ع- برنامج قائم على الفروق الدلالية لتتمية

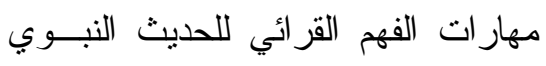

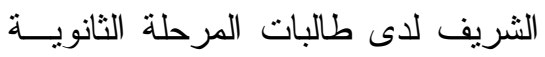

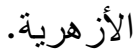
0- برنامج قائم على التطور الدلالي لتتمية مهارات الفهم القرائي للحديث النبــوي الثريف لدى طالبات المرحلة الجامعية. 7- برنامج قائم على الاتشتقاق الدلالي لتتمية

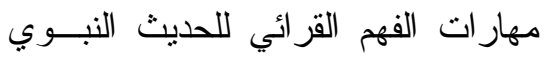
الشريف لدى طلاب كلية التربية. V- برنامج قائم على الحقول الدلالية لتتمية مهار ات الفهم القرائي للحديث النبـــوي الشريف لاى طلاب المرحلة الإعداديــة الأزهرية.

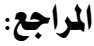

I- إبر اهيم بن يوسف أبو إبحاق(Y I • Y):

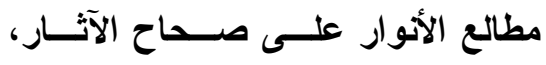

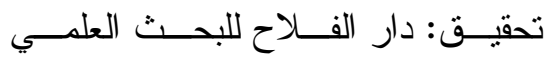

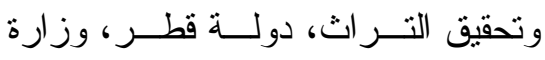

$$
\text { الأوقاف و الثؤون الإسلامية. }
$$

ץ- إير اهيم كمال الدين الدمـشقيّ (1911):

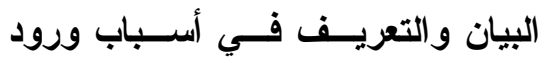
الحديث الثريف، تحقيق: سيف الــدين الكاتب، بيروت، دار الكتاب العربي. r- إير اهيم محمود طلب حشيش (1) ( ب):

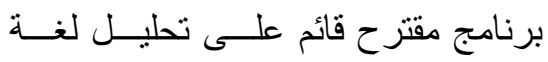


ماجستير ، غزة، الجامعة الإسلامية، كلية

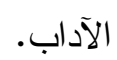

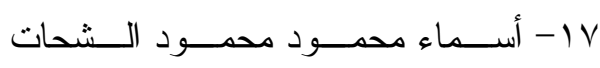

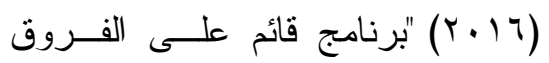

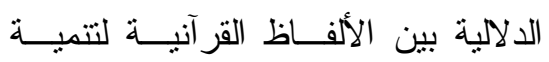

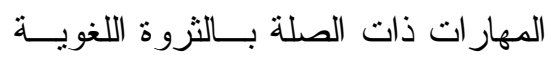
لطلاب كلية التربية شعبة اللغة العربية،

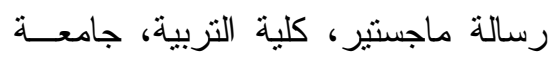

$$
\text { دمياط. }
$$

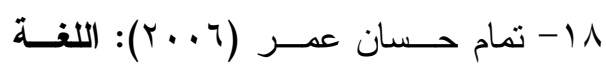

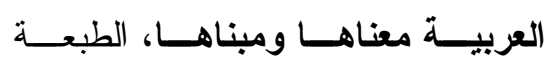
الخامسة، القاهرة، عالم الكتب. 9 1 - جلال الدين السيوطي ( ع 9 1):الإنقان

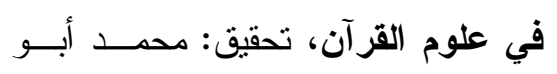
الفضل إبر اهيم، الهيئة المصرية العامــة فئة

$$
\text { للكتاب. }
$$

• ץ- جلال الدين السيوطي(991 (1): المزهر في علوم اللغة وأنواعها، تحقيق: فؤاد

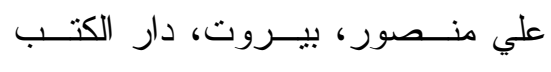
العلمية.

ا (ץ- جمال الدين ابن منظور (ـ99 99 ): لسان

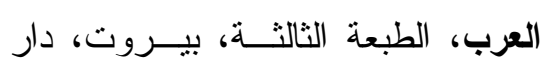

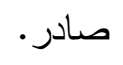
r r- جنان منصور كاظم الجبوري(0 . . r):

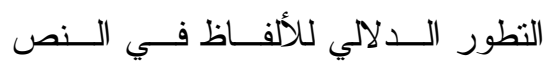

النبوية، المدينة المنورة، مجمع الملـــك فهر لطباعة المصحف الشريف. . 1 - أحمد بن فارس(9V9 ( ) ): معجم مقاييس اللغة، تحقيق: عبد السلام محمد هارون،

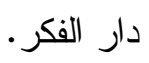

1 - أحمد بن محمد القـسطلاني (r 999 (1): شرح القسطلاني = إرشــاد الـساري لشرح صحيح البخاري، الطبعة السابعة، مصر ، المطبعة الكبرى الأمبرية.

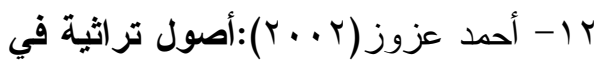
نظرية الحقول الدالية، دمثق، اتحــاد

$$
\text { الكتاب العرب. }
$$

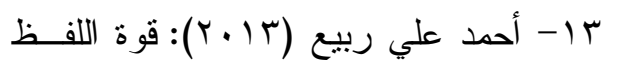

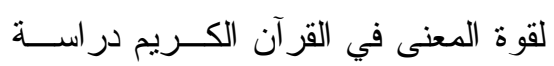
تحليلية، مجلة كلية الاراسات الإسلامية

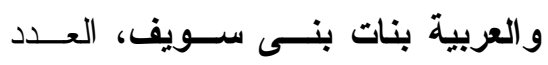
الخامس.

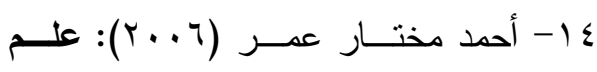
الدلاهة، الطبعة السادسة، القــاهرة، دار عالم الكتب.

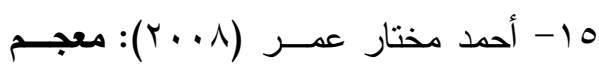
اللغة العربية المعاصرة، القاهرة، عـالم الكتب. 17- أحمد مصطفى أحمد الأسطل(1) (1)

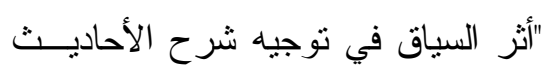

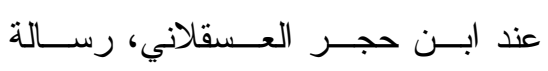


السعودية، وزارة التعليم العالي، جامعــة ام القرى، كلية اللغة العربية.

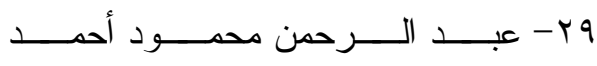

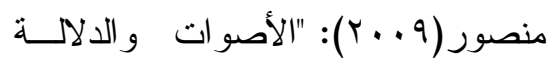
في الميسر في شرح مــصابيح الـسنة

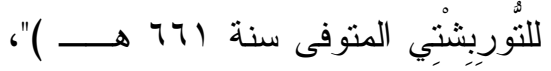
جامعة الأزهر ، الزقازيق، كليــة اللغـــة العربية. •r- عبد السلام صالح (1) (1): مباحسـ الفروق في التقسير وعلوم القرآن، مجلة

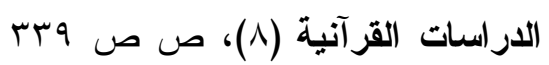
. EYA اب- عبد القادر بن عمر البغدادي(99V ()): خزانة الأدب ولب لباب لسان العــرب،

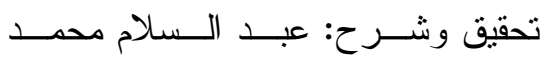
هارون، الطبعة الرابعة، القاهرة، مكتبة الخانجي.

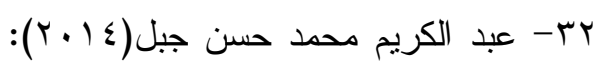
في علم الدلالة دراسة تطبيقية في شرح

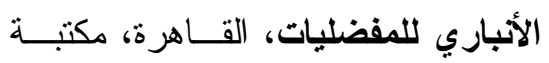

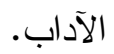

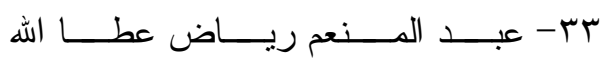

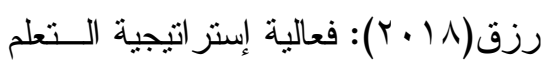

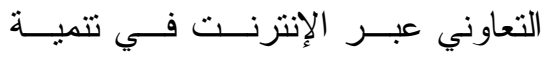

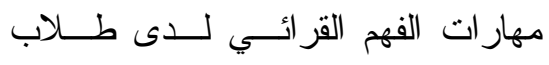

القر آني - در اســـة بلاغيــة-، رســالة دكتور اه، جامعة بغداد، كلية التربية. rr- حسن شحاته وزينب النجــار (r . . r): معجم المصطلحات التزبوية والنفسية، القاهرة، الدار المصرية اللبنانية. ع צ- الحسين بن محمد آيت سـعيد(د ـ ت): السنة النبوية وحي من الله محفوظــة

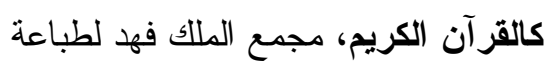
المصحف الثريف بالمدينة المنورة. Or- الحسين بن محمد بن عبد الهـ شـرف

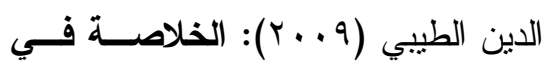

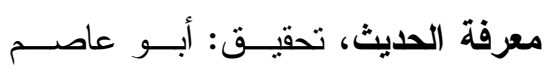

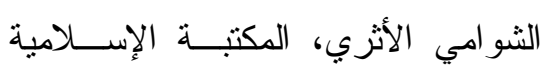

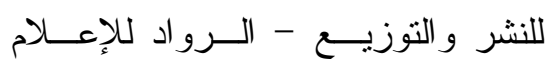
و النشر.

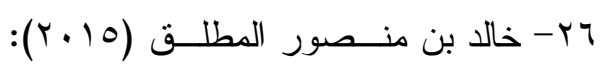
منهج الإمام جمال الدين السرَُّّرَّي في

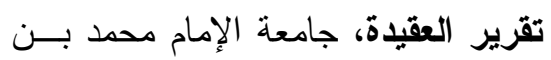
سعود الإسلامية، كلية أصول الدين.

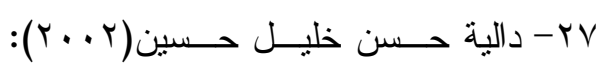
أسلوب الشرط ودلالاته فــي الحـديث

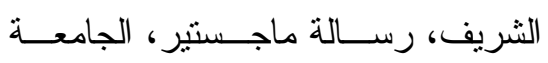
الأردنية، كلية الدراسات العليا.

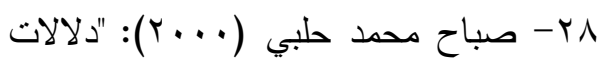
الألفاظ الإسلامية في الأحاديث النبوية"،

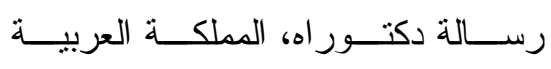


و ب- عمار ساس(997 (): تحليـلـل الـــص الأدبي ومبدأ ربط النحو بالبلاغة، مجلة

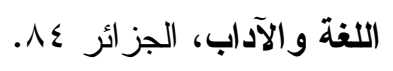

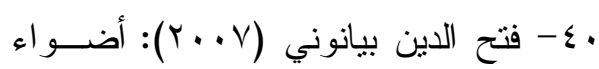

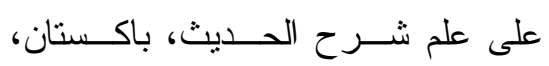

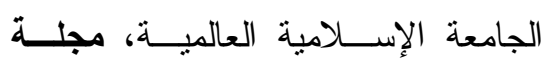

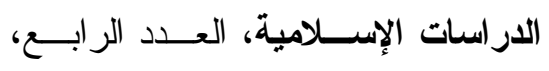

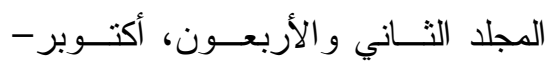

$$
\text { ديسمبر · }
$$

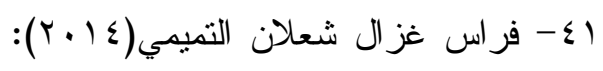

أثز استراتيجية تحليل السمات الدلاليــة

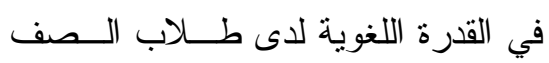

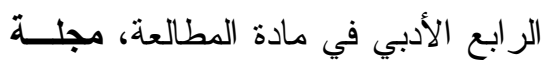

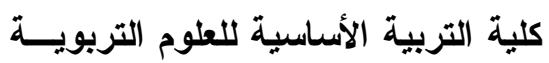

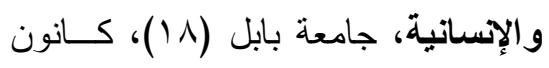

$$
\text { أول، ص ص والانسانه، جانعة بايل }
$$

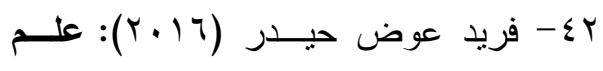

الالالة: دراسة نظرية تطبيقية، الطبعة

الثانية، القاهرة، مكتبة الآداب.

rع - أبـــو الفـضل زيــن الــدين إبــر اهيم

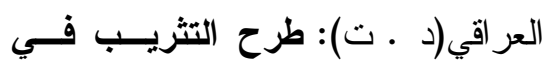

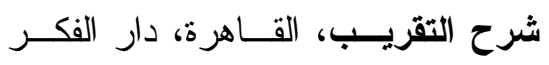

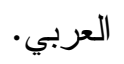

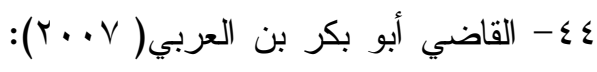

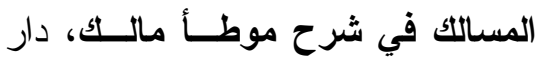

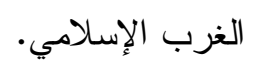

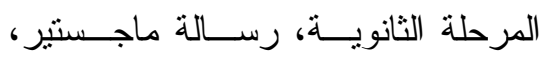
جامعة المنصورة، كلية التربية.

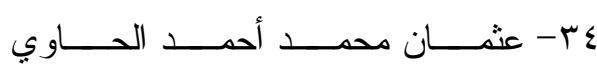

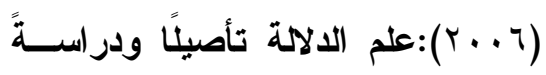

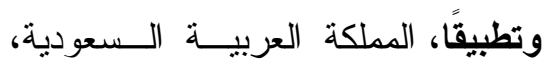

الدمام، مكتبة المتتبي.

هr- عقيد خالد حمودي العزاوي؛ عماد بن

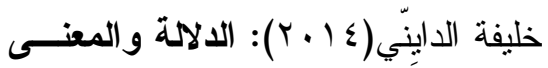

دراسة تطبيقية، دمــشق، ســـوريا، دار

العصماء.

بr- علي أحمد مــدكور (ع ا.بץ): تتميــة

الوعي بمقاصد الثريعة الإسلامية مـنـ

خلال منهج الحديث الــشريف المقــرر

على طلاب المرحلة الثانويــة، مجلــة

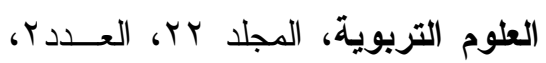

ص ص ص 0 ص - .01.

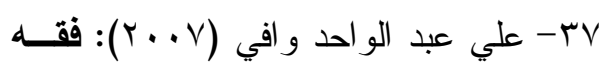

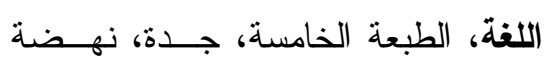

مصر للطباعة و النشر و التوزيع.

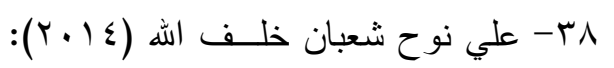

"الدرس الصوتي و الدلالي فــي كتــاب

المسالك في شرح موطأ مالك للقاضـي ولي

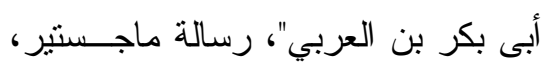

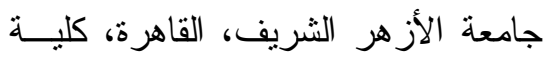

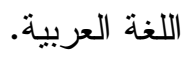




$$
\begin{aligned}
& \text { (0- محمد بن إسماعيل البخاري (Y.... } \\
& \text { الجامع المسند الصحيح المختصر مسن بـن } \\
& \text { أمور رسول الله × وسنته وأيامسـه = } \\
& \text { صحيح البخاري، تحقيق: محمد ز هيــر } \\
& \text { بن ناصر الناصر ، دار طوق النجاة. }
\end{aligned}
$$

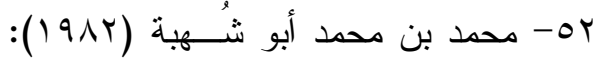

$$
\begin{aligned}
& \text { الوسيط في علوم ومصطلح الحـديث، } \\
& \text { القاهرة، دار الفكر العربي. }
\end{aligned}
$$$$
\text { ror- محمد حسن حسسن جبـل (999 (19): }
$$$$
\text { تعليل الأسماء، طنطا، التركي للكمبيوتز }
$$$$
\text { وطباعة الأوفست. }
$$

؟0- محمد حسن حسن جبل (Y • (Y): علم

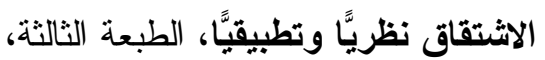

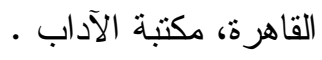

00- محمد حسن حسن جبل(0 . . ץ): علـم

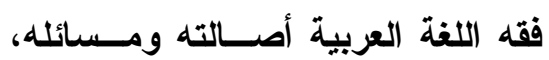

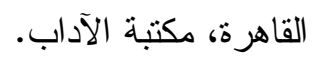

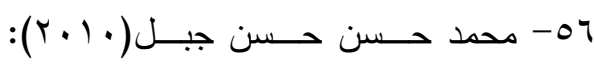

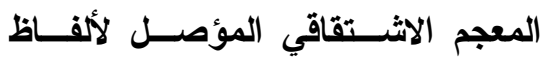

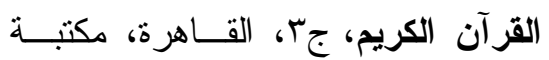

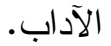

-OV محمد عبــــ العــال الـسيد إبــراهيم

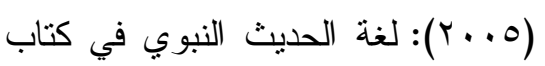

طرح التثريب في شرح الثقريب للحافظ

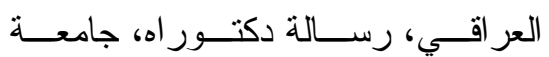

0ـ - كريم زكـي حسـام الــدين( ( . ب):

أصول تراثية في اللسانيات الحديثـة، الطبعة الثالثة، القاهرة.

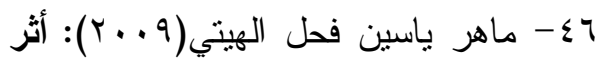

اختلاف الأسانيا والمتون في اخــتلاف

الفقهاء، بيروت، دار الكتب العلمية.

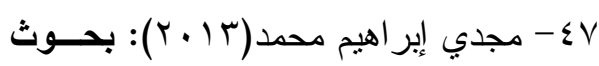

في علم الدلاية بين القدماء و المحدثين، الهين

القاهرة، الهيئة المصرية العامة للكتاب.

^ـ - محمــد أحمــد عبـــد العــاطي عبــد

الباقي(10 • ب): "الاختز ال الدلالمي فــــي

الحديث النبوي، در اسة في ضوء نظرية

تحليل الخطاب"، جذور، النادي الأدبـي في نئي

النقافي بجـدة، الـسعودية، العـدد إع،

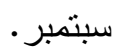

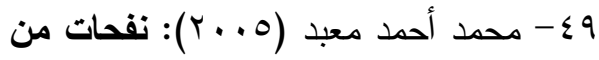

علوم القرآن، الطبعة الثانية، القـــاهرة،

$$
\text { دار السلام. }
$$

•- محمد السيد منولي الزينـي (T . . ب):

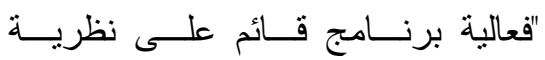

المخططات العقلية باستخدام الحاسـوبـ

في تتمية مهار ات الفهم القر ائي للقـــرآن

الكريم ومهار ات تدريسه لدى الطـــلاب

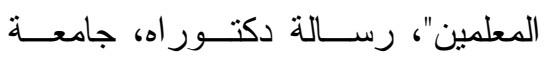

المنصورة، كلية التزبية. 


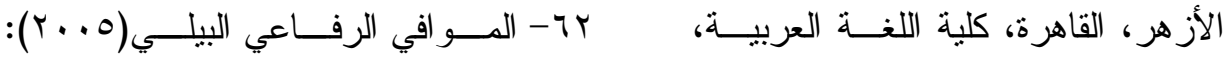

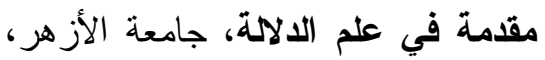

$$
\begin{aligned}
& \text { المنصورة، كلية اللغة العربية. }
\end{aligned}
$$

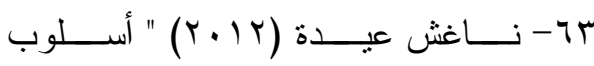

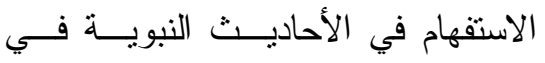

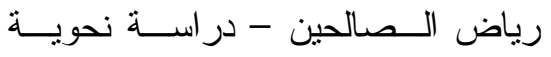

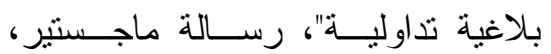

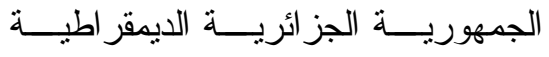

$$
\begin{aligned}
& \text { الثعبية، جامعة مولود معدــري، كليــة }
\end{aligned}
$$

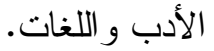

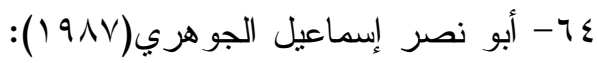

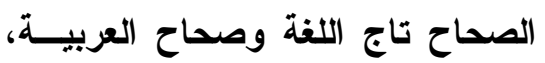

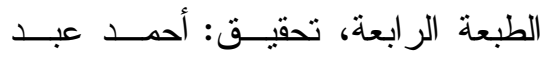

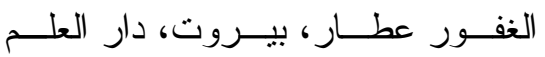

$$
\begin{aligned}
& \text { للملايين. } \\
& \text { 70-نــور الــدين بـن مختــار الخــادمي }
\end{aligned}
$$

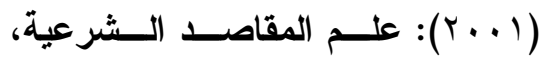

$$
\begin{aligned}
& \text { المملكـــة العربيــة الــسعودية، مكتبــــة }
\end{aligned}
$$

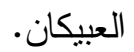

$$
\begin{aligned}
& \text { للطباعة و النشر و النوزيع. }
\end{aligned}
$$

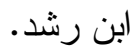

